\title{
Tetracycline antibiotics
}

\section{Journal Article}

\section{Author(s):}

Ramachanderan, Raghavendra; Schaefer, Bernd

Publication date:

2021

Permanent link:

https://doi.org/10.3929/ethz-b-000494980

Rights / license:

Creative Commons Attribution 4.0 International

Originally published in:

ChemTexts 7(3), https://doi.org/10.1007/s40828-021-00138-x 


\title{
Tetracycline antibiotics
}

\author{
Raghavendra Ramachanderan ${ }^{1} \cdot$ Bernd Schaefer $^{2} \mathbb{D}$
}

Received: 25 October 2020 / Accepted: 8 March 2021 / Published online: 27 April 2021

(c) The Author(s) 2021

\begin{abstract}
Tetracyclines belong to the first broad-spectrum, well-tolerated, and easy-to-administer antibiotics, which are effective against plague, cholera, typhoid, syphilis, Legionnaire's disease, and anthrax. Some can also be used to treat malaria, Lyme disease, tuberculosis, Rocky Mountain spotted fever, and leprosy. Humans first encountered these chemical species involuntarily in ancient times, as evidenced from the analysis of bone samples dating back more than 1500 years. Shortly after World War II, they were "rediscovered" at Lederle Laboratories and Pfizer as a result of an intense search for new antibiotics. Their bacteriostatic action is based on the inhibition of protein biosynthesis. Since the structure elucidation by Robert Woodward, Lloyd Hillyard Conover, and others in the 1950s, tetracyclines have become preferred targets for natural product synthesis. However, on industrial scale, they became readily available by fermentation and partial synthesis. Their casual and thoughtless use in the initial decades after launch not only in humans but for veterinary purposes and as growth-enhancement agents in meat production rapidly led to the emergence of resistance. In an arms race for new antibiotics, more and more new drugs have been developed to deal with the threat. In this ongoing endeavor, a remarkable milestone was set by Andrew Myers in 2005 with the convergent total synthesis of (-)-doxycycline, as well as numerous azatetracyclines and pentacyclines, which has inspired chemists in the pharmaceutical industry to discover novel and highly active tetracyclines in recent years.
\end{abstract}

\section{Graphic abstract}

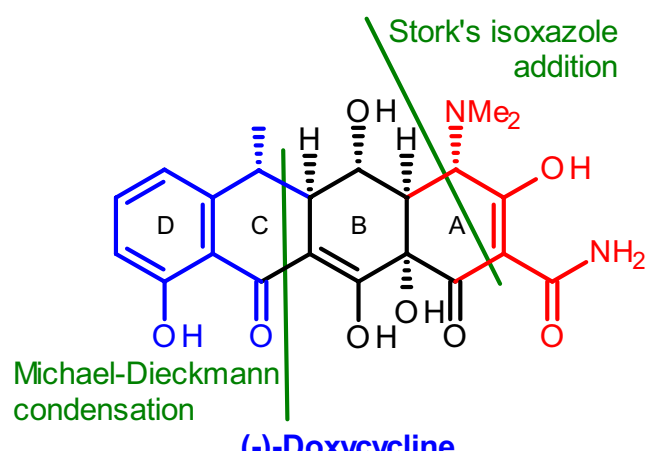

Keywords Tetracycline $\cdot$ Antibiotic $\cdot$ Total synthesis $\cdot$ Biosynthesis $\cdot$ Plague

Bernd Schaefer

bernd.g.schaefer@basf.com

1 Department of Biosystems Science and Engineering, ETH

Zurich, Basel, Switzerland

2 Ruprecht-Karls-Universität Heidelberg; BASF SE,

RCS/ON-B009, 67056 Ludwigshafen am Rhein, Germany 


\section{Info box: Instructions for the reader}

This review is not intended to be read in a linear fashion. If you are interested in a particular topic, please feel free to jump directly to the section of interest. The content ranges from 1.0 Introduction

2.0 Tetracyclines in late antiquity

3.0 Discovery of the tetracyclines

4.0 Pharmacology

5.0 Resistance

6.0 Structure-activity relationships

7.0 Total synthesis

8.0 Industrial synthesis

9.0 Concluding remarks

In this review, we emphasize total and industrial syntheses. If your focus is on the pharmacology, resistance, or structureactivity relationships of tetracyclines, please consult the relevant literature cited.

As you browse through this review, you will find numerous info boxes that contain interesting and sometimes entertaining information, but they are not essential to the story and can be skipped.

In order to simplify retracing the numerous building blocks, the drawings of most chemical syntheses are in color. The color code is consistent within a total synthesis, but not between two different ones.

\section{Introduction}

One of the most recent and dramatic epidemics of pneumonic plague took place in 1994 in Surat, a metropolis of 4.4 million people on the Indian west coast [1]. The World Health Organization (WHO) recorded 6344 suspected cases, 234 victims, and over 50 deaths. Fearing the disease, more than an estimated one million people fled the city (Fig. 1). It is likely owing to the relatively low virulence of the disease-causing strain of the pathogen Yersinia pestis combined with the quick and timely deployment of tetracycline that the plague was contained. United Nations International

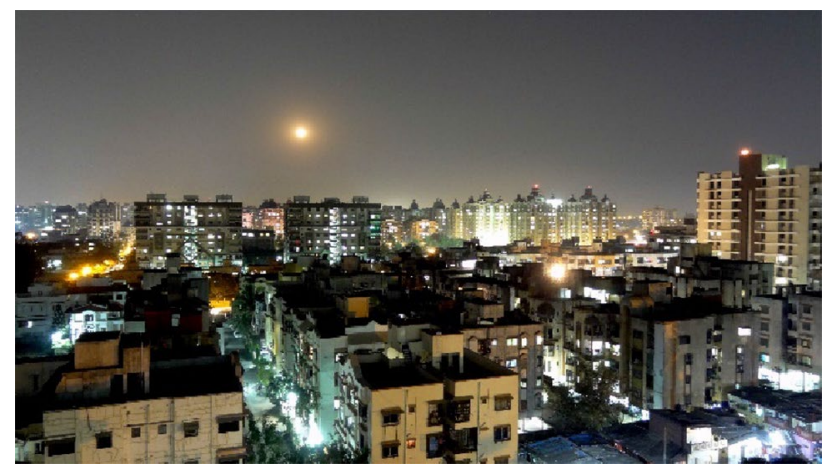

Fig. 1 The outbreak of plaque at the city of Surat brought public life to a halt. Restrictions affected food vendors, restaurants, municipal gatherings, air and sea travel. The collapse of trade and tourism caused an estimated 1.8 billion US dollars worth of economic damage [4]. (ㄷ Hemant meena)
Children's Emergency Fund (UNICEF) supplied over 11 million tetracycline capsules to India from a warehouse in Copenhagen. The tablets were distributed to the populace in Surat at no charge, and the Indian government increased the stocks of tetracycline by 5 tons [2]. Later plague outbreaks have also been recorded in Algeria (2003), Congo (2006), and Madagascar (since 2008) [3].

Overnight, the massive plague pandemics that have scourged humanity throughout history returned to the minds of the global public $[5,6]$. The path of migration of the pathogen has been precisely traced today by sequencing its genome, coupled with archeological findings by American [7-9] and British research programs [10, 11].

- It was the Justinian plague (541-750) (caused by Yersinia pestis Antiqua), a bubonic plague introduced from Egypt by a grain ship, that first affected Constantinople and the Byzantine empire and later decimated lives in the entire Mediterranean region up to north of the Alps [12].

- The second pandemic (caused by Yersinia pestis Medievalis) broke out in 1347 in China and made its way to Europe via the Silk Road and the sea where it wreaked havoc until 1750 (Fig. 2).

- Finally a third pandemic (caused by Yersinia pestis Orientalis), which started in 1855 in Yúnnán, a province in southwest China, spread into Mongolia, Manchuria (1899), Russia (1900-1927), India (1896-1898), South Africa (1899-1902), then via Hong Kong (1894) to Hawaii (December 1899), San Francisco (March 1900), and finally South America (1908-1945) by sea [13].

\section{Info box: The plague in literature}

The theme of infectious diseases has long attracted prominent authors. In the frame narrative of The Decameron by the fourteenth-century Italian author Giovanni Boccaccio (1313-1375), ten young women and men take shelter in a secluded villa two miles outside of Florence to escape the Black Death, which had afflicted the city in 1348. The bubonic plague, which struck the city of London in 1665 inspired Daniel Defoe (1660-1731) in his novel A Journal of the Plague Year. However, in contrast to the diary of Samuel Pepys (1633-1703), it is a fictional account of the experiences of a man made during the Great Plague of London.

In 1943, the Italian journalist Raoul Maria de Àngelis (1908-1990) published the novel La peste a Urana (The Plague in Urana). Four years later, a very similar plot was featured by Albert Camus (1913-1960). His world-renowned novel La Peste (The Plague) is about a fictional outbreak of plague in the Algerian city of Oran. In it, a doctor encounters humanity and solidarity despite the hopelessness and absurdity of the fight against the plague. In 1973, the play Il sonno dei carnefici (The sleep of the executioners) by the Italian politician, entomologist, and playwright Giorgio Celli (1935-2011) refers to the plague in Seville (1647-1652). Finally, the French novelist Marcel Pagnol (1895-1974) also contributed a story about the plague, depicting the devastation of Marseille in 1720. Les Pestiférés (The plague victims) was published posthumously in $1977[15,16]$. 

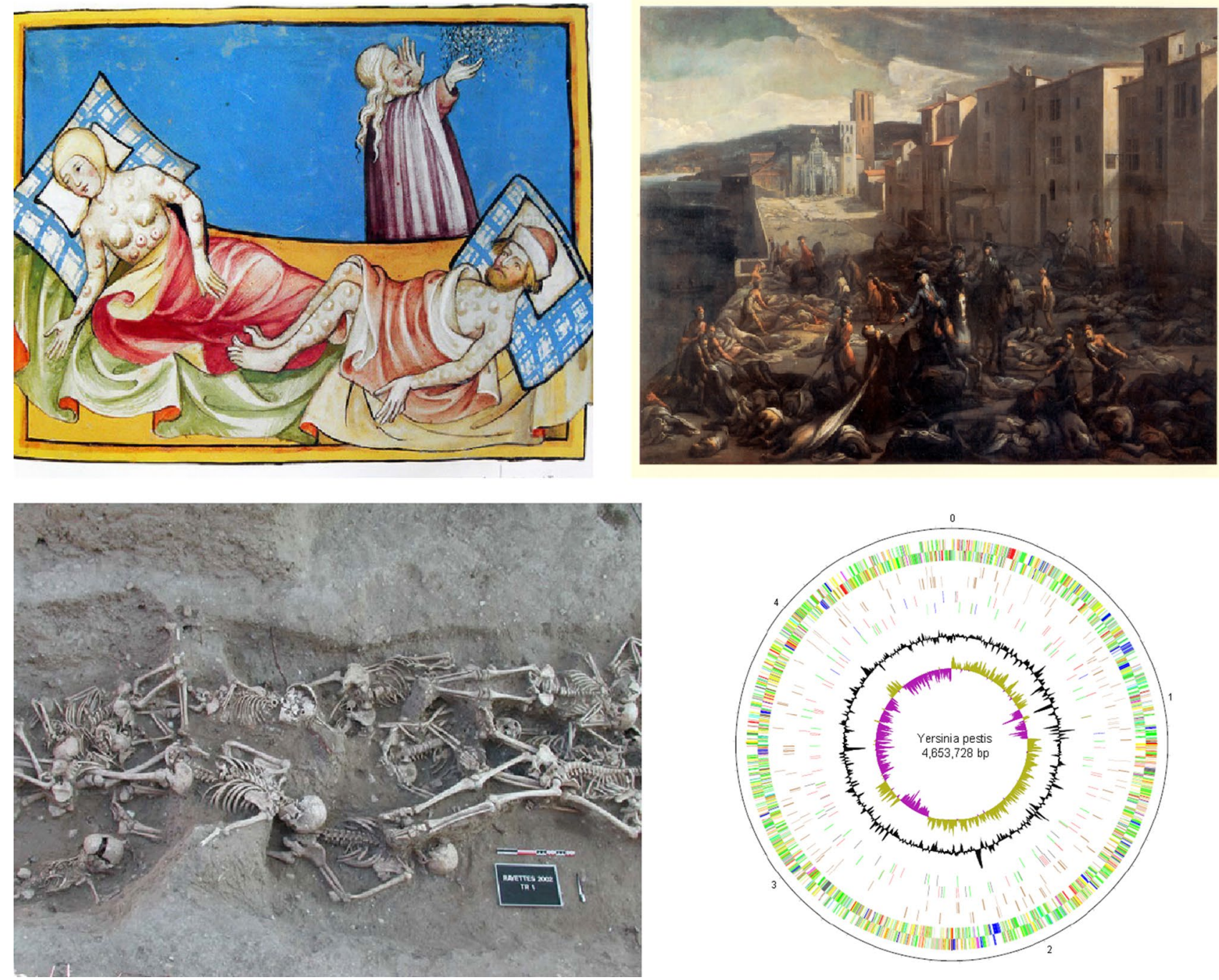

Fig. 2 Testimonies of the Black Death depicting the grief, desperation, and doom of civilization, but also hope, resulting from science and medicine, in a rather abstract manner. The illustrations range from the Swiss Toggenburg Bible from 1411, the plague in Marseille in 1720 by Michel Serre (1658-1733), a mass grave of the bubonic plague from 1720-1721 in the coastal town of Martigues, in Provence, and a circular representation of the Yersinia pestis Orientalis genome [8]. The sample derived from a fatal human case of primary pneumonic plague in the USA in 1994 [14]. (@ public domain, S. Tzortzis, Julian Parkhill)
There was great concern globally that the disease would spread once again, particularly since international trade and transport routes were difficult to monitor, let alone seal off. Fortunately, owing to exceptional, and far from obvious circumstances, the epidemic in Surat could be managed well with tetracycline, not only in that it could quickly help the affected people but could also prevent mass panic.

The foundation to an effective treatment for plague was laid by two brave doctors in 1894 who travelled to
Hong Kong to investigate the cause of the outbreak. The French Alexandre Emile Jean Yersin (1863-1943) and the Japanese Kitasato Shibasaburō (1853-1931) both independently identified Yersinia pestis as the causative agent of plaque (Fig. 3).

Yersina pestis is a zoonotic pathogen, endemic in rodents. Humans contract plague from the bite of infected fleas, direct contact with diseased animals, or via inhalation of their aerosols. Various forms of the plague have been described. The most common types are the bubonic, 
Fig. 3 Alexandre Yersin researched in the most primitive conditions in Hong Kong on behalf of the Pasteur Institute. Nevertheless, on 20 June 1894 he succeeded in isolating the pathogen from a lymph node of a plague victim and transferring it to mice and guinea pigs. A scanning electron micrograph shows Yersinia pestis bacteria in the colon of an infected flea. It is a gram-negative, non-motile, rod-shaped coccobacilliform bacterium (@ public domain)
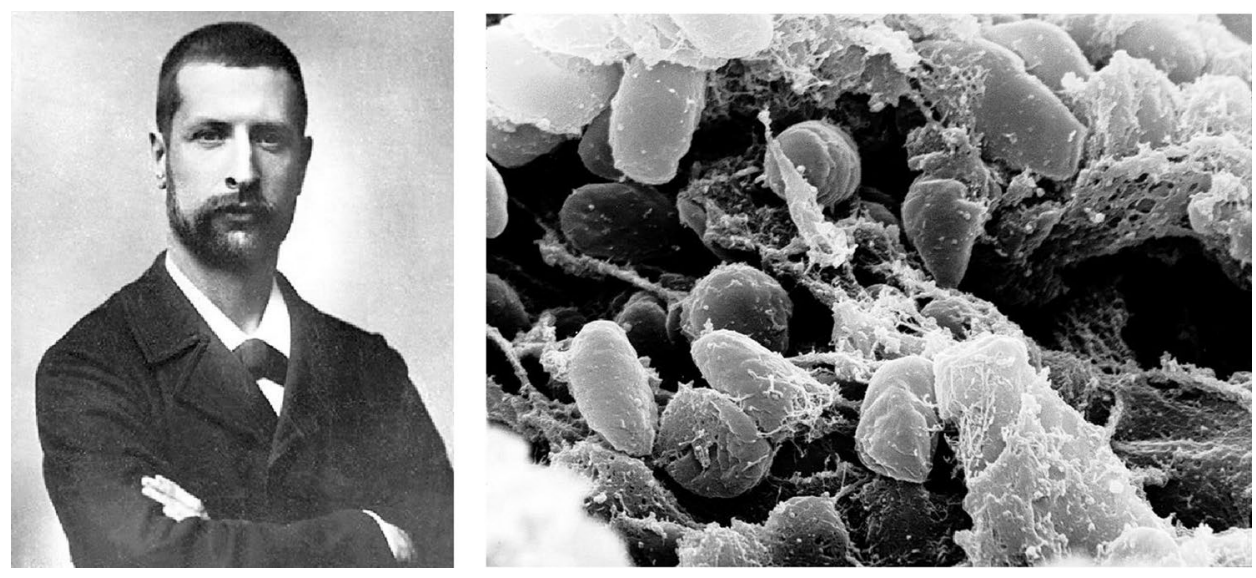

pneumonic, and septicemic plague. The pharyngeal and gastrointestinal plagues do not occur as frequently. Without treatment, plague is a severe and often fatal illness, with a mortality rate of $30-100 \%$. Fortunately, the discovery of numerous classes of antibiotics over the course of the twentieth century provided us several antimicrobials for prophylaxis and/or treatment of plague, including aminoglycosides (streptomycin and gentamicin), chloramphenicol, fluoroquinolones, and tetracyclines [17, 18].

If only the way of living and the diet of the Nubians from the Ballana period (350-550 AD) had been researched earlier-much human suffering might have been spared.

\section{Tetracyclines in late antiquity}

"It was like unwrapping a mummy, only to find the corpse wearing earphones and a pair of sunglasses" [19], wrote the anthropologist George J. Armelagos (1936-2014) from Emory University in Atlanta, Georgia, about his discovery of tetracyclines in a 1600-year-old Nubian mummy in 1980. Tetracyclines are broad-spectrum antibiotics, the first of which, aureomycin, was discovered in 1948 in the Lederle Laboratories in Pearl River, New York. It was hence remarkable that old African cultures had already encountered these.

In 1962, Armelagos' team went on an excavation expedition from the University of Colorado on the western bank of the Nile in the city of Wadi Halfa in Sudan with the aim of rescuing important Nubian cultural artifacts from the floods caused by the elevation of the Aswan Dam, and the ensuing expansion of Lake Nasser and Lake Nubia (Fig. 4) [20].

Eighteen years later Armelagos' graduate student Debra Martin, in Henry Ford Hospital in Detroit, Michigan, cut thin sections of the left femur of a mummy from a by then flooded Nubian grave from the Ballana period (350-550 AD) and used a fluorescence microscope instead of a light microscope which was being used at the time for another routine

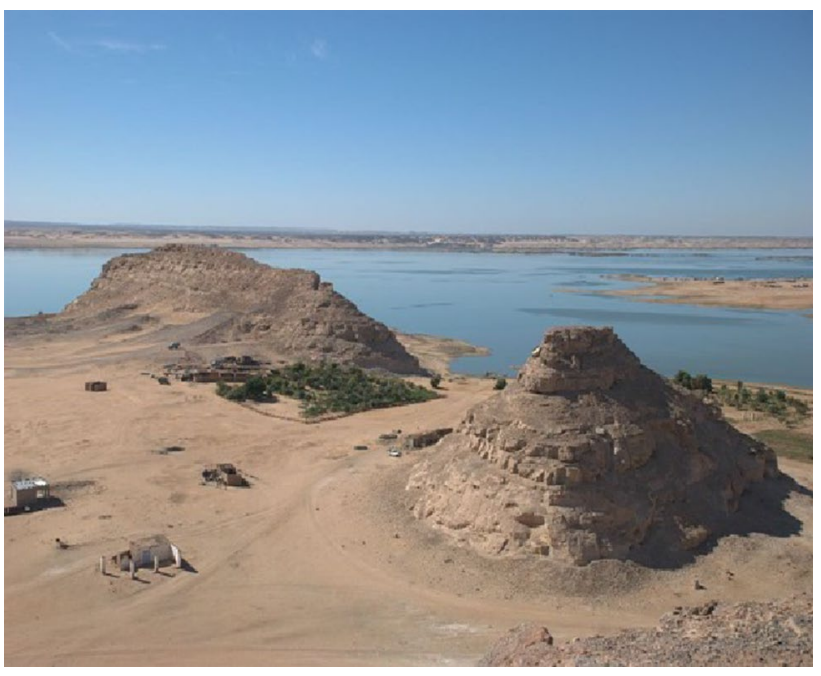

Fig. 4 Inselbergs of Wadi Halfa on the eastern bank of Lake Nubia (C Bertramz)

examination [21, 22]. She noted bright yellow-green fluorescence in the bone material at a wavelength of $490 \mathrm{~nm}$. Since in the same lab the team of Harold Frost, head of orthopedics at Henry Ford Hospital, used tetracycline to determine bone growth, which fluoresced at the same wavelength, it was quickly suspected that this was indeed the cause of the fluorescence of this ancient bone material. Careful remeasurements confirmed this suspicion (Fig. 5) [23].

Later, tetracycline could be detected from 25 mummified corpses from the Dakhla oasis in Egypt from Roman times (400-500 AD), in human bones from Batn-el-Hajar, Sudan (550-1450 AD) and from the necropolis of Hesban, Jordan (2 BC-4 AD) [24-26]

James Boothe, a chemist from American Cyanamid, furthermore extracted the active substance from the 1600-yearold Nubian skeleton and showed that it had still not lost its antibacterial potency [21, 22]. Finally in 2010, mass 
Fig. 5 The chemical structure of tetracycline. It induces yellow-green fluorescence of bone material (@) Shirley Sabo, Emory University, Anthropology Department)
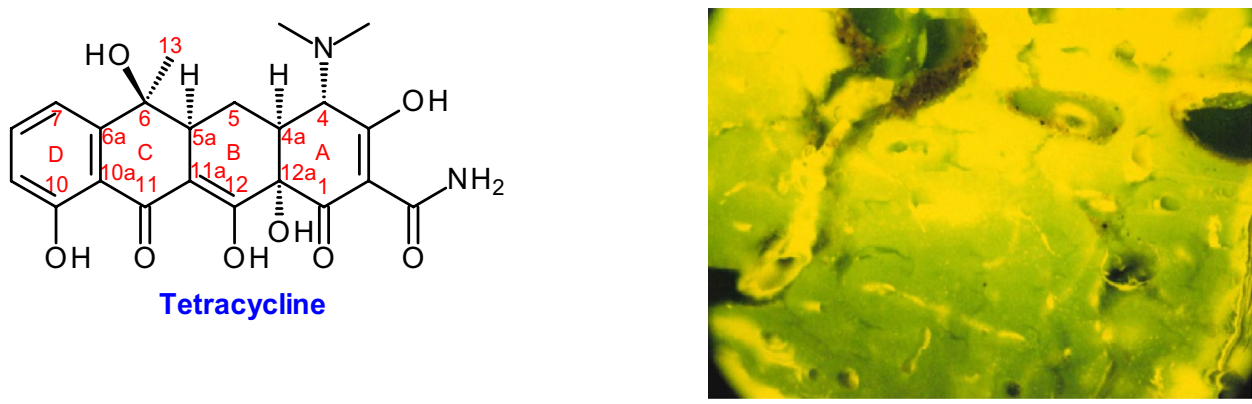

spectrometry was used to detect tetracycline in the bones of a 4-year-old child from a Nubian graveyard [21, 27].

The Nubians likely stored their wheat, barley, and millet in burrows, becoming ideal conditions for tetracyclineproducing Streptomyces that thrive in warm, humid, alkaline conditions. In the preparation of bread dough and beer, they multiply and produce pharmacologically active concentrations of tetracyclines that were consumed by the people over time likely unbeknownst to them [23]. One could say that 1600 years lay between man's indeliberate and deliberate use of tetracycline as an antibiotic.

\section{Discovery of the tetracyclines}

During the Second World War, potent antibiotics were a scarce commodity. Alexander Fleming (1881-1955) had already discovered penicillin in 1928, but this was produced in far from sufficient quantities by the end of the war. There was hence a feverish search by several pharmaceutical companies to discover new compounds.

\section{Info box: Plague in biological warfare research}

It was not only about the peaceful use of these novel medicines, or the treatment of wounded soldiers, but about the defense against a concrete threat: from 1940 to 1942, in disregard of human rights, the Japanese Imperial Army tested the use of the plague pathogen as a biological weapon on prisoners of war and Korean and Chinese civilians [28].

The new story of tetracycline began in 1943, when Benjamin Minge Duggar (1872-1956) was granted emeritus status as a plant physiologist at the age of 71 from the University of Wisconsin (Fig. 6) [29]. Still driven by science, he became a consultant at a mycological research lab at Lederle Laboratories, an affiliate of American Cyanamid, in Pearl River, New York, where an earnest search for new antibiotics was made. He quickly focused on soil organisms. After a test of around 3500 strains for

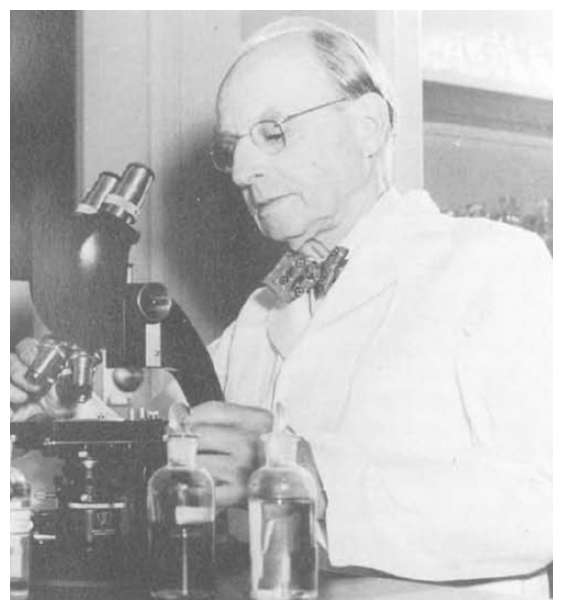

Fig. 6 Prof. Dr. Benjamin M. Duggar. Actually, he was more than a consultant [33]. He also worked in the lab and made the greatest discovery of his life after he had retired. (@ public domain)

antibacterial activity, he discovered an interesting Streptomyces species in a soil sample from Sanborn Field, an experimental agricultural testing ground of the University of Missouri. The Streptomyces species showed marked activity against staphylococci and streptococci (Fig. 7) [30]. Duggar proposed the name Streptomyces aureofaciens, genus Streptomycetes for the yellow-colored microorganism, and correspondingly aureomycin for the active compound [31, 32].

\section{Info box: Five-year old Tobey Hockett}

Five-year old Tobey Hockett was one of the first patients treated with aureomycin. In early 1948 he was diagnosed with a ruptured appendix at Johns Hopkins Children's Hospital in Washington DC. Although emergency surgery was successful his condition deteriorated by a serious infection. He was facing immediate death, because the few antibiotics available at that time proved ineffective. In desperation Tobey's parents consented a treatment with aureomycin, which recently was provided by Lederle. Within months Tobey Hockett fully recovered [34]. 

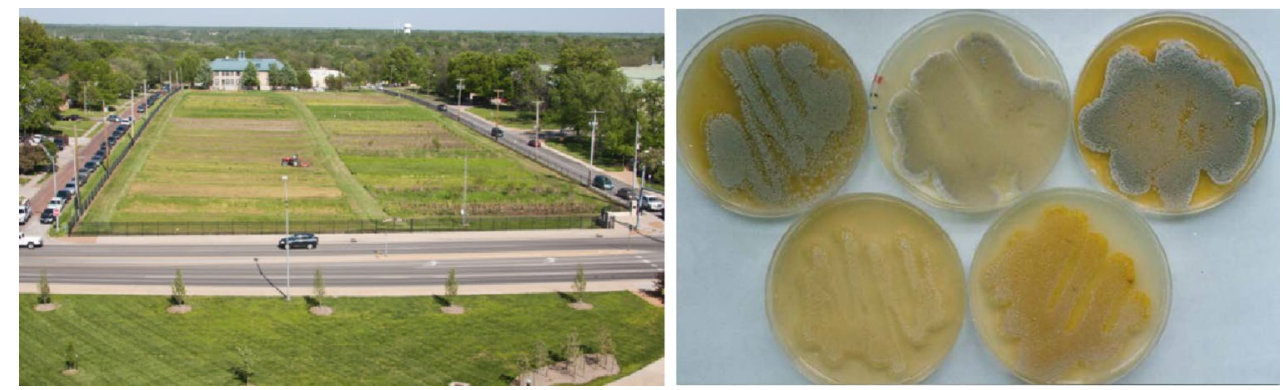

Fig. 7 Agricultural testing ground of the University of Missouri. The sample came from plot 23 of the test site, untreated since 1888, of the University of Missouri and was planted with timothy grass (Phleum pratense). The mycelium-building bacterium from this sample, ini-

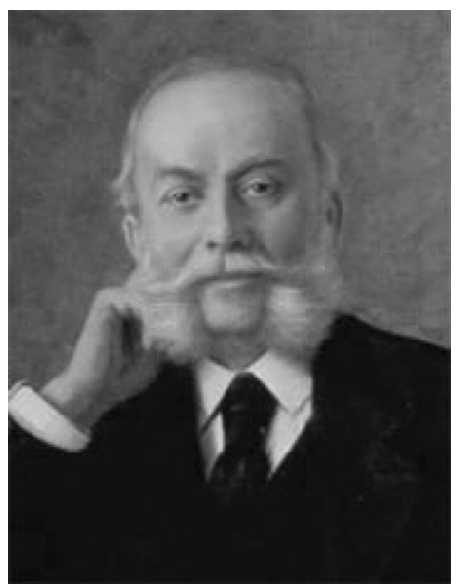

Fig. 8 Karl Pfizer (1824-1906) was a German chemist hailing from Ludwigsburg, who emigrated to the USA in the early 1840 s and founded Charles Pfizer \& Company with his cousin Charles Erhart in Brooklyn, New York in 1849. It was only after the commercialization of terramycin in the 1960s and 1970s that it evolved into the world's largest pharmaceutical company (@) public domain) tially A-377, later called Streptomyces aureofaciens (photograph), produces a potent compound against, for example, Staphylococcus aureus (@) lwtwb8, PD Dr. Joachim M. Wink, Helmholtz-Zentrum für Infektionsforschung $\mathrm{GmbH}$, Braunschweig)

At around the same time, Alexander Finlay at Pfizer (Fig. 8) was also actively searching for new compounds. At the end of the 1940s, Pfizer conducted around 20 million tests from a collection of approximately 135,000 soil samples. The samples were from mine shafts, deserts, jungles, mountaintops, and ocean trenches. However, the sample that turned out most promising in 1949 came from the premises in Terre Haute, Indiana, which had belonged to Pfizer since 1948. It contained the soil bacterium Streptomyces rimosus, which also produced a golden active compound that was initially named terramycin $[35,36]$.

Within 2 years, the Pfizer team, in cooperation with Robert B. Woodward (1917-1979), clarified the structure of aureomycin and terramycin (Fig. 9). In view of systematics and the structural features of the compounds, they were renamed chlortetracycline and oxytetracycline [37]. Final uncertainties regarding the structure were clarified by NMR and crystallographic analyses [38, 39].
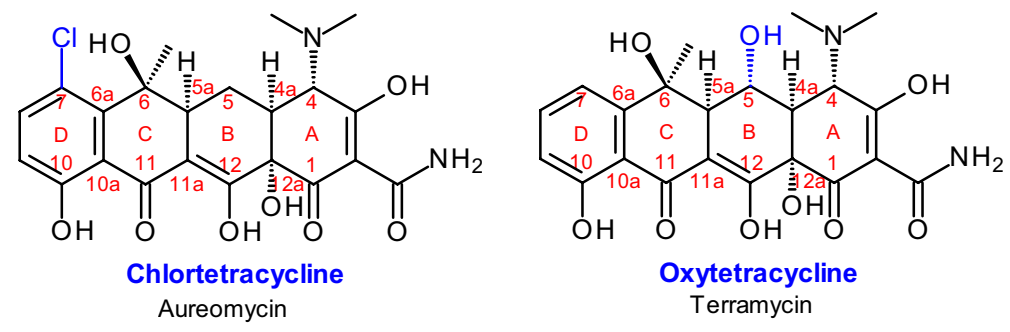

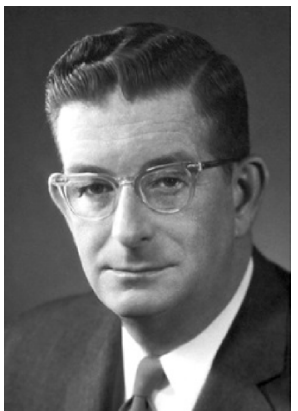

Fig. 9 The structure determination of chlortetracycline and oxytetracycline are masterpieces of Woodward's work. The photograph shows him in 1965, when he was awarded the Nobel prize in chemistry, for his synthesis of complex organic molecules. Sir Derek Barton (1918-
1998) commented: "Woodward took a large piece of cardboard, wrote on it all the facts and, by thought alone, deduced the correct structure for terramycin. Nobody else could have done that at the time." [40] (C) public domain) 

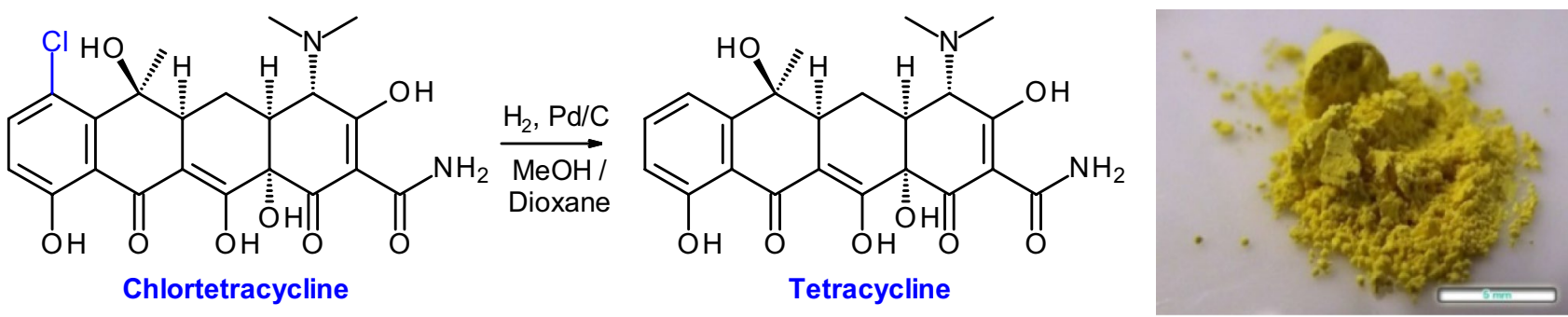

Fig. 10 Tetracycline, a golden yellow solid, can be synthesized by both partial synthesis and by fermentation (@ Rillke)

In 1953, Lloyd Hillyard Conover (1923-2017), an employee at Pfizer, discovered that the basic chemical structure of the tetracyclines could be obtained by hydration of chlortetracycline and filed a patent for the process (Fig. 10) [41]. Not much later, Cyanamid, Heyden Chemicals, Bristol-Myers, Squibb, Upjohn, and other companies also filed patents for the partial synthesis and fermentative synthesis of tetracyclines. A three decade long bitter rivalry flared between the companies, and certain firms did not shy from industrial espionage and violating antitrust laws [42]. Perhaps the largest losses of several 100 million dollars were made by American Cyanamid, as a previous employee of Lederle Laboratories, Dr. Sidney Martin Fox, stole microfilms of classified documents and bacterial cultures between 1959 and 1962 and resold them to Italian pharmaceutical companies [43].

\section{Pharmacology}

\section{Tetracyclines used as antibiotics}

Tetracyclines are not only effective against the plague but can also be used to treat cholera (Vibrio cholerae), typhoid fever (Salmonella enterica subsp. enterica ser. Typhi), syphilis (Treponema pallidum), Legionnaire's disease (Legionella pneumophila), and anthrax (Bacillus anthracis). Some members of this drug class are also used in the treatment of malaria (Plasmodium parasites), Lyme disease (Borrelia burgdorferi, Borrelia afzelii, Borrelia garinii), tuberculosis (Mycobacterium tuberculosis), query fever (Coxiella burnetii), Rocky Mountain spotted fever (Rickettsia rickettsii), and leprosy (Mycobacterium leprae).

The bioavailability and pharmacology of the tetracyclines are strongly dependent on the presence of some indispensable structural features, such as the vinylogous acid and a keto-enol system at the $\mathrm{A}$ and the $\mathrm{BC}$ rings, respectively. They enable the formation of ionic and zwitterionic species, which substantially affect conformation and thereby contribute to the biological activity of the tetracyclines [44]. On the other hand, acidic or basic conditions are detrimental to tetracyclines, they do not just lead to protonation/deprotonation of the amino and hydroxy groups but also to irreversible degradation reactions, as will be outlined later [45]. Once the tetracycline has entered the target cell, the formation of a metal complex is a crucial prerequisite for efficient binding at the various ribosomal binding sites (Fig. 11) [46-50].

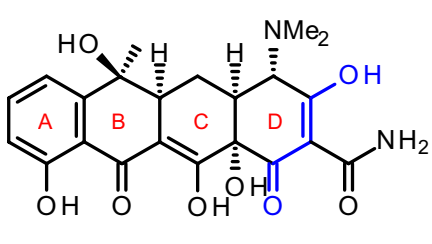

neutral state
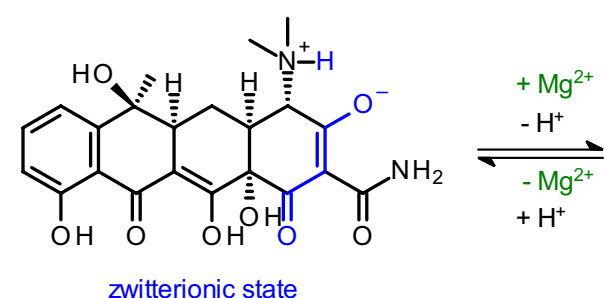

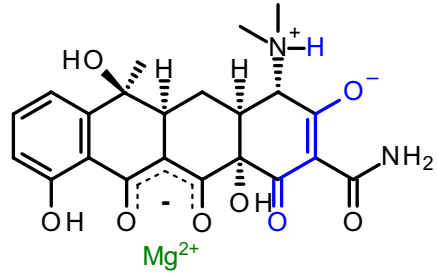

Fig. 11 Various states of tetracycline important for its pharmacological activity. The enol and the adjacent keto group at position 1-3 (blue) constitutes a vinylogous carboxylic acid, which like amino acids, leads to an equilibrium of the neutral and the zwitterionic state.
Additionally, in the presence of divalent cations, preferentially $\mathrm{Mg}^{2+}$ and $\mathrm{Ca}^{2+}$, the keto-enol system at position 11-12 (green) give rise to an equilibrium with the corresponding chelates 

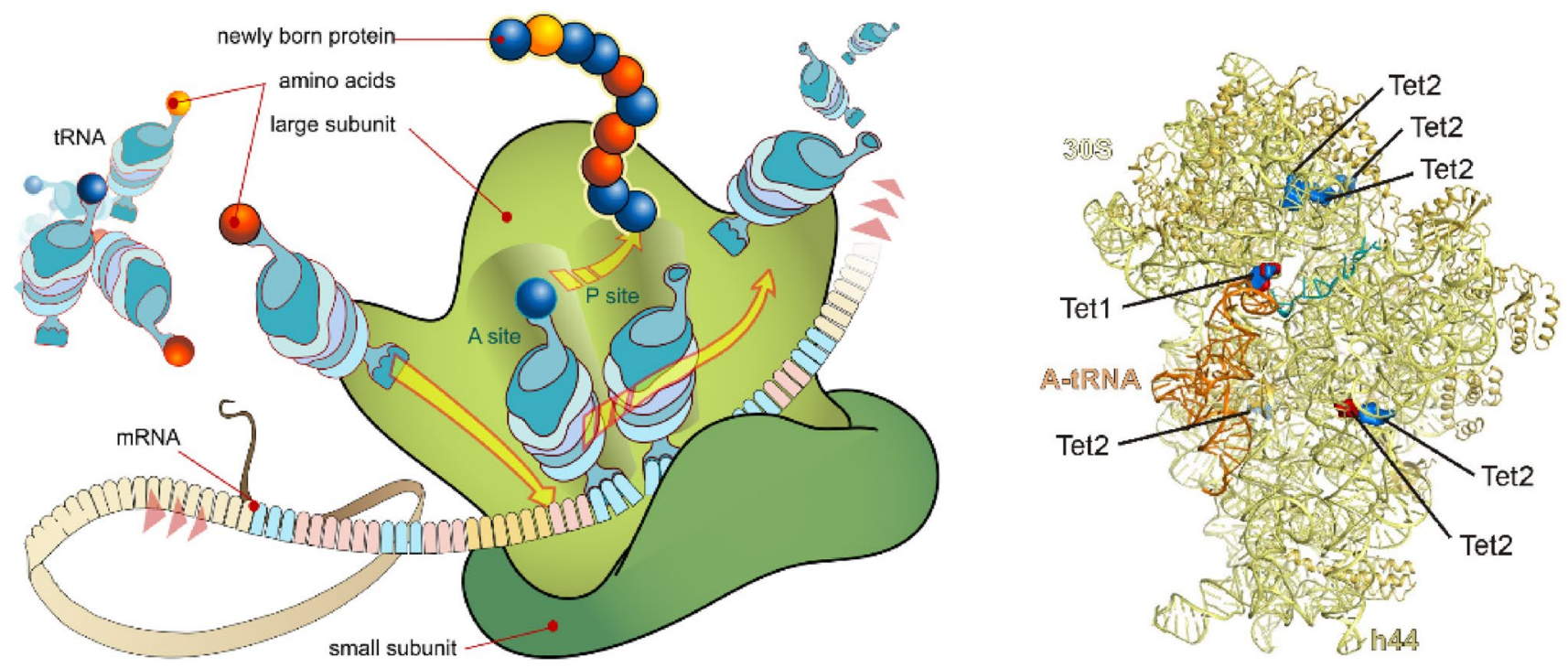

Fig. 12 Scheme showing the translation of mRNA and the synthesis of proteins by a ribosome. Tetracyclines inhibit the accommodation of incoming aminoacyl-tRNA into the ribosomal binding site, and thereby prevent the addition of new amino acids to the growing pep- tide (left). Tetracycline binds to the primary binding site (Tet1) and to multiple lower occupancy secondary binding sites (Tet2) of the $30 \mathrm{~S}$ subunit (right). (@ public domain, Daniel N. Wilson)

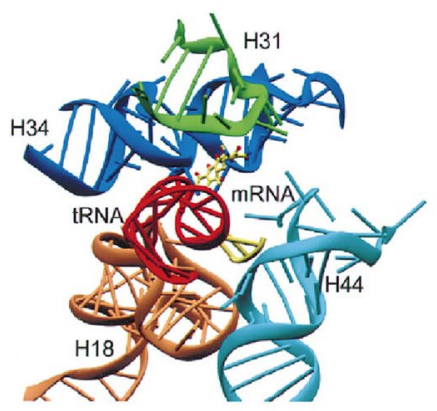

Fig. 13 RNA components close to the primary binding site of tetracycline Tet- 1 of the 30S subunit of Thermus thermophilus [48]. It consists of the 16S ribosomal RNA [54] and 19 full proteins [55]. The binding pocket is formed by the irregular minor groove of the rRNA helix H34 (residues 1196-1200:1053-1056) (blue) and the loop of helix H31 (residues 964-967) (green). The model also displays the rRNA helices H18 (brown), H44 (cyan), the tRNA (red), and mRNA

The bacteriostatic action of the tetracyclines is based on their inhibition of protein biosynthesis of the target pathogens. Several X-ray crystal structure analyses have shown that they bind reversibly at specific binding sites on the A site of the 30S subunit of the ribosome, and thereby prevent the loading of amino acidconjugated tRNAs when translating mRNAs (Figs. 12 and 13) [48, 49, 51-53]. This inhibits the elongation of the native polypeptide chain, an essential process of bacterial growth.

Eukaryotic ribosomes also bind tetracyclines, but with an affinity about 15 -fold lower than that of bacterial ribosomes (yellow) (Protein Data Bank: 1HNW). Interactions of tetracycline at position 1-3 and 10-12a within the $16 \mathrm{~S}$ rRNA primary site 51 [56]. The charged side of tetracycline coordinates magnesium ions to interact with the backbone of residues h34 and h31. The substituents at position $4 \mathrm{a}-9$ can be modified to some extent to tune selectivity and overcome resistance

( $K_{\mathrm{d}} 30 \mu \mathrm{M}$ and $1-2 \mu \mathrm{M}$, respectively) [57]. On the other hand, there are significant differences in tetracycline uptake, making eukaryotic cells less susceptible to these antibiotics [56].

\section{Non-antibiotic applications of tetracyclines}

Since the 1950s tetracyclines have also been used to treat disorders which are not necessarily related to an infectious etiology, but inflammation. The anti-inflammatory properties of tetracyclines can be traced back to several beneficial effects [58]: 


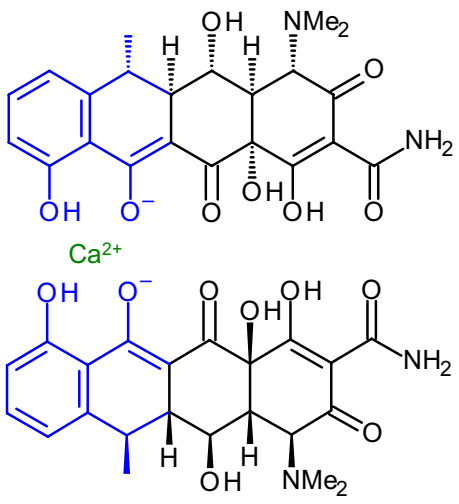

Fig. 14 Doxycycline-calcium complex [67]: when deposited in tooth enamel, for instance, undesired discolorations may result

1. The application of tetracyclines in dermatology is based predominantly on the inhibition of matrix metalloproteinases produced by inflammatory cells in connective tissues [59]. Metalloproteinases are zinc-dependent proteases and involved in both physiological and pathophysiological processes, such as embryogenesis, tissue remodeling, and inflammation. A prominent application is the treatment of periodontitis with sub-antimicrobial doses of doxycycline [60].

2. Tetracycline, minocycline, and doxycycline cause a decreased production of neutrophil chemotactic cytokines, which are involved in the genesis of inflammation, at doses below the minimum inhibitory concentration of the causative bacteria, e.g., Cutibacterium acnes, linked to the skin condition of acne.

3. Calcium is required for the assembly of microtubules, which are essential for the movement of cells. In the early phase of the inflammatory process leukocytes start to migrate. By complexation of intracellular calcium, tetracyclines are able to retard the progress of inflammation (Fig. 14).

4. Minocycline inhibits T cell proliferation and the reduction of interleukin-2, interferon- $\gamma$, and tumor necrosis factor alpha, which constitutes the rational for its offlabel application in rheumatoid arthritis [61-63].

5. In the inflammatory response, hydrolases, such as alphaamylases and phospholipase $\mathrm{A}_{2}$, play a crucial role because they are essential enzymes in the activation of inflammatory mediators, including prostaglandins. Thus, inhibition of phospholipase $\mathrm{A}_{2}$ by tetracyclines, comprising minocycline and to some extent doxycycline, suppresses inflammation $[64,65]$.

6. Tetracyclines have been shown to be strong antioxidants, thereby exerting neuroprotective properties and inhibiting angiogenesis, which makes sub-antimicrobial doses of doxycycline a drug of first choice for the treatment of rosacea (Fig. 15) [66].

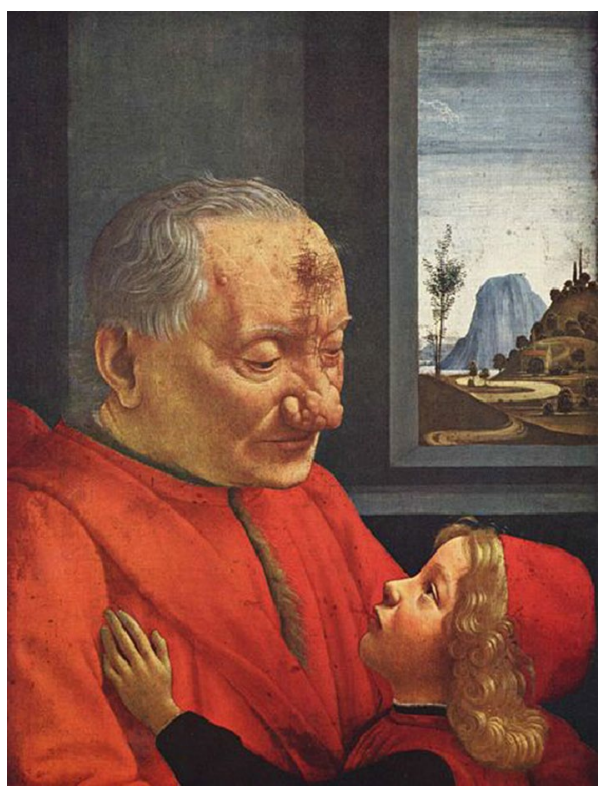

Fig. 15 Rosacea in painting: "An Old Man and his Grandson" by Domenico Ghirlandaio (1449-1494, Florentine painter, Louvre, 1488). (@ public domain)

\section{Resistance}

The tetracyclines belong to the first broad-spectrum, welltolerated, and easy-to-administer antibiotics that could be economically synthesized by fermentation [51]. Tetracyclines quickly became the treatment of choice for a plethora of bacterial ailments not only in people but also for animals in veterinary settings [51]. Robert Stokstad (1913-1995) and Thomas Jukes (1906-1999) at Lederle realized in 1949 that subtherapeutic doses of chlortetracycline could also positively affect growth of poultry, opening doors to the market segment of growth enhancement in meat production [68]. It is therefore not surprising that within a few years the first resistant strains of various pathogens such as Shigella dysenteriae (causative of shigellosis) cropped up.

Today, four principle mechanisms of bacterial resistance against tetracycline have been described $[51,56]$ :

1. Reduction of intracellular tetracycline concentration by active efflux. The most common forms of bacterial resistance to tetracycline are those that actively transport the invaded antibiotic out of the cell, before it can reach its target, the ribosome. The first gene for a membraneintrinsic efflux pump in Enterobacteriaceae was discovered in 1974 by Stuart B. Levy at Tufts University in Boston [69]. Today at least 28 such genes have been cataloged. They are predominately found in gram-negative bacteria and are coded on conjugative plasmids, which also carry other resistance genes, allowing rapid spreading among other bacteria. After entering a resist- 
ant bacterial cell, tetracycline (Tc) chelates $\mathrm{Mg}^{2+}$ and the complex $[\mathrm{MgTc}]^{+}$binds to a Tet repressor, which is associated with conformational changes and weakening of the binding of the repressor to the corresponding DNA operator. Ultimately, this leads to the expression of the efflux pump gene. The efflux pump protein inserts into the cytoplasmic membrane and exports $[\mathrm{MgTc}]^{+}$ (coupled with the uptake of $\mathrm{H}^{+}$), thereby preventing blockage of the 30S subunit, which has a 1000-fold lower affinity to $[\mathrm{MgTc}]^{+}$than the Tet repressor [70].

Alongside this proton motif force mechanism, $\mathrm{Na}^{+}$-dependent systems are also known [71, 72]. Efflux pumps confer resistance to first-generation tetracyclines, while they are less effective against those of the second and third generations.

2. Disruption of the interaction of tetracycline with the $30 \mathrm{~S}$ subunit by ribosomal protective proteins, such as TetM and TetO (Fig. 13) [53]. The second most common strategy with which bacteria become resistant to tetracyclines is the production of soluble cytoplasmic proteins that bind to ribosomes and in a guanosine-5'triphosphate-dependent manner cleave the ribosome-tetracycline complex. Ribosomal protective proteins have little or no effect on the minimum inhibitory concentration (MIC) of third-generation tetracyclines, such as tigecycline, eravacycline, and omadacycline, not only because of an increase in binding affinity compared to tetracycline but also the C-9 side chain which hinders the ribosomal protective proteins from accessing nucleotide $\mathrm{C} 1054$ to displace the drug from its binding site on the ribosome.

3. Deactivation of tetracycline by hydroxylating at position 11a. Aerobic bacteria can become resistant to tetracyclines by producing flavin adenine dinucleotide monooxygenases, such as TetX and Tet 37, which hydroxylate C-11a (Fig. 16). The hydroxylation at position 11a perturbs magnesium complexation and thereby reduces the binding affinity to the ribosomal binding sites. Moreover, the 11a-hydroxytetracyclines turn out to be unstable under physiological conditions and decompose without any enzyme action. Even third-generation tetracyclines, such as tigecycline, originally designed to circumvent resistance relying on active efflux of tetracyclines, and ribosomal protection proteins, bind to TetX and are deactivated by oxidation [73-76].

4. Mutation at the binding site for tetracyclines at the $30 \mathrm{~S}$ subunit. When compared to the wild type, some strains have multiple mutations on the ribosome that provide broad resistance to several tetracyclines, including doxycycline, minocycline, and to some extent tigecycline [77].

\section{Info box: Resistance of Yersinia pestis}

The hazard of antibiotic resistance is amplified by the ability of bacteria to exchange resistance genes between different strains via bacterial conjunction (horizontal gene transfer). In 1995, two strains of Yersinia pestis were discovered in isolates from patients from Madagascar, exhibiting plasmid-mediated single- and multiple-drug resistance. While the strain Yersinia pestis 16/95 gained single-drug resistance against streptomycin by a plasmid called pIP1203, probably from Escherichia coli, Yersinia pestis 17/95 developed resistance against eight antibiotics, including various tetracyclines, by incorporating the pIP1202 plasmid, which is most closely related to pP99018 and pP91278 from Photobacterium damselae. Up to now, these two strains seem to be confined to Madagascar, but they constitute an enduring threat, to be spread over the globe, to countries in which plague is endemic, e.g., by wildlife trade, vanilla exports, and tourism $[17,18]$.

\section{Structure-activity relationships}

Propelled by the rapid emergence of resistance, the pharmaceutical industry has constantly developed new structural frameworks based on tetracyclines in the last 50 years in the hope of tackling growing antibiotic resistance. Although this has met with limited success, it has afforded insight into the influence of specific structural moieties on the pharmacological action of the compound [56, 78, 79].

The tetracyclines are classified into three generations. Soon after the discovery of the first generation of tetracyclines, all of them obtained by fermentation, a second generation of tetracyclines with better pharmacological
Fig. 16 Oxidative deactivation of tetracycline. 11a-Hydroxytetracycline binds magnesium very poorly, which likely reduces its affinity to the ribosome

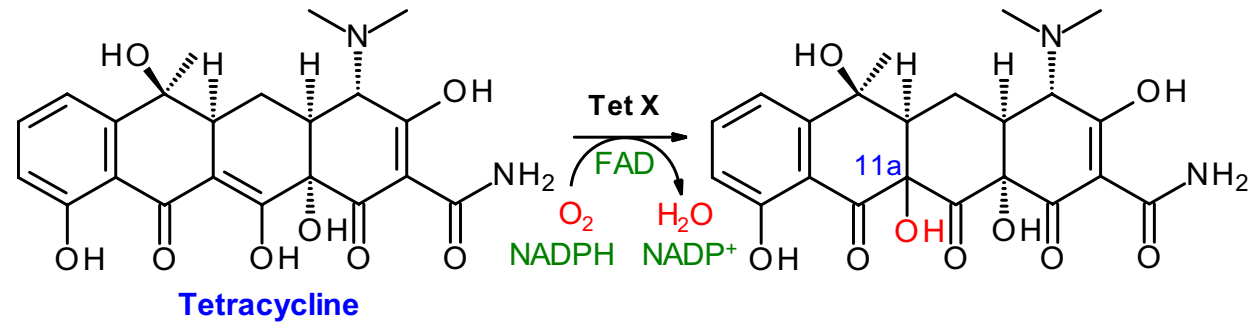


Table 1 The generations of tetracyclines

Generation

Structure

Name

Company

Discovered/published

1<smiles>CN(C)[C@H]1C(O)=C(C(N)=O)C(=O)[C@]2(O)C(O)=C3C(=O)c4c(O)ccc(Cl)c4[C@@H](O)[C@@]3(C)C[C@H]12</smiles>

Chlortetracycline

Lederle

1948<smiles>CN(C)C1C(O)=C(C(N)=O)C(=O)[C@]2(O)C(O)=C3C(=O)c4c(O)cccc4[C@@H](O)[C@@]3(C)C3[C@H](O)[C@H]1[C@H]32</smiles>

Oxytetracycline

Pfizer

1949

1<smiles>CN(C)[C@H]1C(O)=C(C(N)=O)C(=O)[C@@]2(O)C(O)=C3C(=O)c4c(O)cccc4[C@@H](O)[C@@H]3C[C@H]12</smiles>

2<smiles>CN(C)[C@H]1C(O)=C(C(=O)NCN2CCCC2)C(=O)[C@]2(O)C(O)=C3C(=O)c4c(O)cccc4[C@@H](O)[C@@H]3C[C@H]12</smiles>

Rolitetracycline

Hoechst

1956

2<smiles>CN(C)[C@H]1C(O)=C(C(N)=O)C(=O)[C@@]2(O)C(O)=C3C(=O)c4c(O)cccc4C[C@H]3[C@@H](O)[C@@H]12</smiles>

2<smiles>CN(C)c1ccc(O)c2c1C[C@H]1C[C@H]3C(N(C)C)C(O)=C(C(N)=O)C(=O)[C@@]3(O)C(O)=C1C2=O</smiles>

3<smiles>CN(C)c1cc(NC(=O)CNC(C)(C)C)c(O)c2c1C[C@H]1C[C@H]3[C@H](N(C)C)C(O)=C(C(N)=O)C(=O)[C@@]3(O)C(O)=C1C2=O</smiles>

Doxycycline

Lederle

1959

Tigecycline

Wyeth

1999

3<smiles>CN(C)c1cc(CNCC(C)(C)C)c(O)c2c1C[C@H]1C[C@H]3[C@H](N(C)C)C(O)=C(C(N)=O)C(=O)[C@@]3(O)C(O)=C1C2=O</smiles> 
Table 1 (continued)

Generation Structure

Fig. 17 Structure-activity relationships of the tetracycline class of compounds [78]

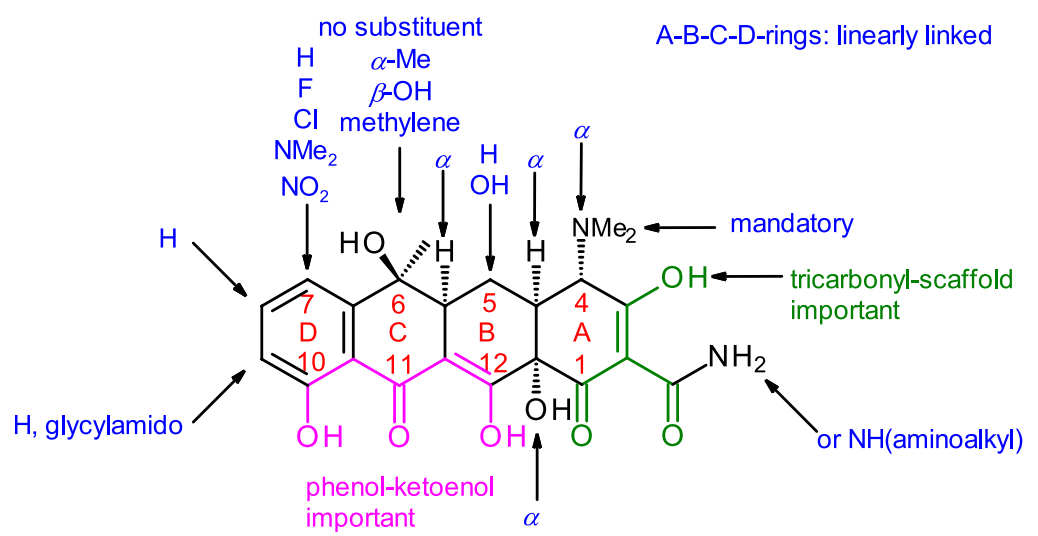

and toxicological properties was made available by partial synthesis primarily by Lederle and Pfizer. The glycylamidotetracyclines with their efficacy against resistant strains comprise the third generation. Azatetracyclines, pentacyclines, and fluorotetracyclines are also considered as new third-generation tetracyclines (Table 1) [80, 81].

The most critical structural features for optimal antibacterial activity are summarized in Fig. 17.

Important in antibacterial efficacy are the linear fusion of the four rings, the absolute configuration at the $\mathrm{C}$ atoms 4, 4a, 5a, and 12a, and also the keto-enol structure in the neighborhood of the phenolic D ring. Aminoalkyl substituents at the amide increase water solubility of the tetracyclines. Different substituents are tolerated at positions 5, 6, and 7. Tetracyclines with a glycylamido group at position 9 show notable activity against bacterial strains whose resistance is a consequence of expression of efflux proteins or ribosomal protective proteins [82].

\section{Total synthesis}

The tetracyclines were associated with a certain fascination since the very beginning, and natural product chemists have been raptured ever since [83]. This was best described by Woodward in his description of the first total synthesis of a biologically active tetracycline: "This work was undertaken in response to the synthetic challenge presented by the diabolical concatenation of atoms present in the tetracycline system." [84] 
Fig. 18 Retrosynthetic considerations of Woodward's total synthesis of racemic 6-demethyl-6-dehydroxytetracycline<smiles>COC(=O)c1cccc(OC)c1</smiles>

rac. 6-Demethyl-6-dehydroxytetracycline
Fig. 19 First part of Woodward's total synthesis of 6-demethyl-6-dehydroxytetracycline<smiles>COC(=O)c1cccc(OC)c1</smiles><smiles>CCC(C)=O</smiles>
$\mathrm{NaH}, \mathrm{DMF}$<smiles>COC(=O)CCl</smiles>

$55 \%$<smiles>COC(=O)CCC(CC(C)=O)(C(=O)OC)C(=O)c1cccc(OC)c1</smiles><smiles>COC(=O)CCC(CCC(C)=O)Cc1cccc(OC)c1</smiles><smiles>COc1ccc(Cl)c2c1C(=O)CC(CCC(C)=O)C2</smiles>

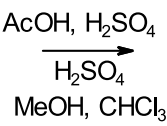

$44 \%$

$\mathrm{NaOH}, \mathrm{H}_{2} \mathrm{O}$

$\underset{\mathrm{Cl}_{2}, \mathrm{AcOH}}{\stackrel{100{ }^{\circ} \mathrm{C}}{\longrightarrow}}$

$\mathrm{I}_{2}$ (cat.)

$\mathrm{HF}, 15^{\circ} \mathrm{C}$

$63 \%$<smiles>COC(=O)CC(C(=O)OC)C(=O)c1cccc(OC)c1</smiles><smiles>C=CC(=O)OC</smiles>

Dioxane, $\mathrm{MeOH}$ $50-70{ }^{\circ} \mathrm{C}$

$88 \%$<smiles>COC(=O)CCC(CC(C)=O)C(=O)c1cccc(OC)c1</smiles><smiles>COc1ccc(Cl)c2c1C(=O)CC(CCC(=O)O)C2</smiles>

$66 \%$

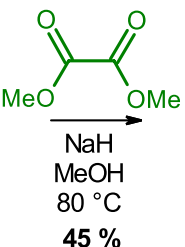<smiles>COc1ccc(Cl)c2c1C(=O)C1=C(O)C(O)=C(C(C)=O)CC1C2</smiles>

\section{Woodward's synthesis of racemic 6-demethyl-6-dehydroxytetracycline}

Woodward's synthesis targeted racemic 6-demethyl-6-dehydroxytetracycline, which he declared a formidable synthetic challenge with regard to its substitution pattern and the three asymmetric centers concentrated on ring A [84]. Consequently, he decided upon a BCD-ring-containing [84] tetrahydroanthracene-2,11-dione derivative as a central intermediate that was synthesized in seven steps from $m$-methoxybenzoic acid methylester (Fig. 18).

A series of condensation reactions, a Michael addition to methylacrylate, saponification, decarboxylation, and re-esterification forms 3-( $m$-methoxybenzoyl)adipic acid dimethylester from $m$-methoxybenzoic acid methyl ester. In the subsequent hydrogenation to remove the keto group, a $\gamma$-lactone (with the red labeled carboxyl function) is formed, which, after continued hydrogenation, leads to the mono acid. For better purification by distillation, this is re-esterified. Following the hydrolysis of the diester, the benzene ring is chlorinated at the $p$-position to the methoxy substituent to prevent the Friedel-Crafts acylation at that position. Subsequent ring closure by cyclodehydration in liquid hydrogen fluoride (Friedel-Crafts acylation), esterification, and condensation with dimethyloxalate forms the B ring (Fig. 19).

Following saponification and decarboxylation, the hydroanthracene triketone is reacted with glyoxylic acid $t$-butylester with catalytic amounts of magnesium methanolate. Dimethylamine is added to the resulting olefin regioselectively at the $\beta$-position relative to the ketone. Addition to the $\beta$-position of the ester is less favored owing to steric reasons. The Mannich base so formed is extremely labile, so the ketone is immediately reduced at $-70{ }^{\circ} \mathrm{C}$ with sodium 
Fig. 20 Second part of Woodward's total synthesis of 6-demethyl-6-dehydroxytetracycline
Fig. 21 Final part of Woodward's total synthesis of 6-demethyl-6-dehydroxytetracycline<smiles>COc1ccc(Cl)c2c1C(=O)C1=C(O)C(O)=C(C(C)=O)CC1C2</smiles><smiles>O=C(O)[C@@H](Cl)C(O)O</smiles><smiles>COc1ccc(Cl)c2c1C(=O)C1=C(O)C(=O)CCC1C2</smiles>

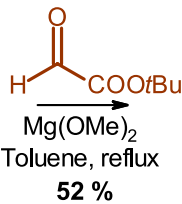<smiles>COC(=O)C=C1CC2Cc3c(Cl)ccc(OC)c3C(=O)C2=C(O)C1=O</smiles>

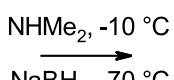
$\mathrm{NaBH}_{4},-70^{\circ} \mathrm{C}$ $69 \%$<smiles>CCOC(=O)[C@H](N)[C@H]1C[C@@H]2Cc3c(Cl)ccc(OC)c3C(=O)C2=C(O)[C@@H]1O</smiles><smiles>COc1ccc(Cl)c2c1C(=O)C1=C(O)[C@@H]3OC(=O)[C@H](N(C)C)[C@H]3C[C@H]1C2</smiles>

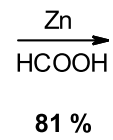<smiles>COc1ccc(Cl)c2c1C(=O)C1=C(O)C[C@@H]([C@H](C)C(=O)O)C[C@H]1C2</smiles>
$\underset{\mathrm{NEt}_{3}}{\stackrel{\mathrm{H}_{2}, \mathrm{Pd} / \mathrm{C}}{\longrightarrow}}$ $91 \%$<smiles>CCCCNC(=O)C(C(=O)OCC)C(=O)OCC(C)C(=O)OCC</smiles><smiles>CCCNC(=O)C(C(=O)OC)=C(O)[C@H]([C@H]1C=C(O)C2=C(O)c3c(cccc3OC)C[C@H]2C1)N(C)C</smiles>

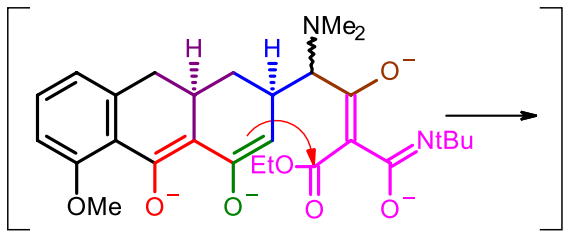<smiles>CCCCNC(=O)C1=C(O)C2=C(O)C3=C(O)c4c(cccc4OC)C[C@H]3C[C@H]2[C@H](N(C)C)C1=O</smiles><smiles></smiles><smiles>C[C@@H]1[C@@H]2C[C@@H]3Cc4cccc(O)c4C(O)=C3C(O)=C2C(O)=C(C(N)=O)C(=O)[C@@H]1N(C)C</smiles>

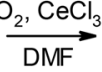<smiles>C[C@H]1C(O)=C(C(N)=O)C(=O)[C@@]2(O)C(O)=C3C(=O)c4c(O)cccc4C[C@H]3C[C@]12C</smiles>

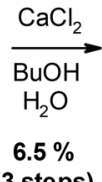

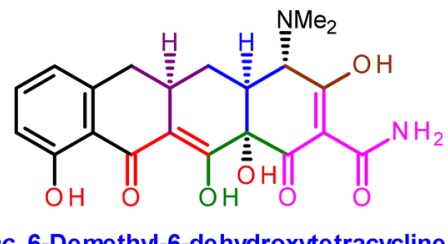

borohydride, thus establishing the relative configuration at three asymmetric centers. The product is then purified by crystallization as hydrochloride salt. Following lactonization, and cleavage of the lactone with zinc/formic acid, dechlorination is performed by catalytic hydrogenation.

This was the starting material with which Woodward endeavored to construct the A ring. Firstly, the carboxylic acid is activated with isopropyl chloroformate as a mixed anhydride and then reacted with magnesium malonic ester amide. Since the product could not be isolated in pure form, the crude product is cyclized using an excess of sodium hydride (Fig. 20).

In the next step, the $N$ - $t$-butyl- and the $O$-methyl groups are cleaved using hydrogen bromide. To conclude the total synthesis, the product is oxidized with oxygen, about which Woodward commented: "The case in hand turned out to be 
by no means the smoothest that we had encountered" [84]. The oxidation at position 12a was finally accomplished with an elaborate setup with oxygen in the presence of 1.3 equivalents of cerium trichloride in DMF. Following epimerization and sophisticated purification the product was obtained in crystalline form with a total yield after three steps of $6.5 \%$. In tests against pathogens, the total synthetic racemic mixture was half as active as its partial synthetic enantiopure counterpart (Fig. 21).

\section{Shemyakin's formal synthesis of racemic tetracycline}

The first total synthesis of racemic tetracycline was from Mikhail M. Shemyakin (1908-1970), from the chemical institute for natural products at the Academy of Sciences in Moscow [85]. Starting material for the synthesis is juglone, which is found in the green husk of the unripe fruits of the walnut tree (Juglans regia L.). In a sequence of six steps, which was later dramatically improved by Phillip Magnus from Indiana University in Bloomington in 1982, the so-called Shemyakin ketone is derived [86]. In ten further steps, racemic 12a-deoxy-5a,6-anhydrotetracycline is synthesized (Fig. 22). This was spectroscopically identical to the (-)-enantiomer isolated from the degradation reaction of tetracycline by Arthur Green and James H. Boothe [87]. The remaining steps, the two hydroxylations-at position C-12a by oxygen using a platinum catalyst and at position C-6 by photochemical oxidation-were already demonstrated by Mikhail Nikolaevich Kolosov in Moscow and Manfred Schach von Wittenau at Pfizer in Groton, Connecticut [88, 89].

Firstly, juglone is reacted with acetoxybutadiene in a Diels-Alder reaction, the anthraquinone derivative is reduced and the aromatic hydroxyl group is protected. A Grignard reaction introduces the methyl group of the later $\mathrm{C}$ ring and the target compound is reached by alkaline hydrolysis of the acetate followed by a Jones oxidation. A Michael reaction with ethyl nitroacetate, an acid-mediated dehydration, and the reduction of the nitro group with zinc follow. After protection of the amino group as a phthalimide, the naphthol is selectively methylated. Shemyakin had initially conceived a simultaneous methylation with the amino group, but the resulting dimethylamino derivative could not be reacted with magnesium malonamate as in Woodward's synthesis (Fig. 23).

Unfortunately, during the hydrolysis of the ester, the phthalimide group is also cleaved, so the amino group must be reprotected. The construction of the A ring is similar to Woodward's synthesis, with the difference that Shemyakin activated the carboxylic acid as the acid chloride and used sodium methyl sulfinyl methylide for cyclization. Upon ultimate removal of the phthalimide group, methyl iodide is used for selective methylation of the amino group. The remaining steps were already documented in the literature (Fig. 24).
Fig. 22 Retrosynthetic considerations of Shemyakin's tetracycline synthesis<smiles>CCOC(=O)[C@@H](c1ccccc1)[C@H]1CC(=O)c2c(c(C)c3cccc(OCc4ccccc4)c3c2OC)C1</smiles>

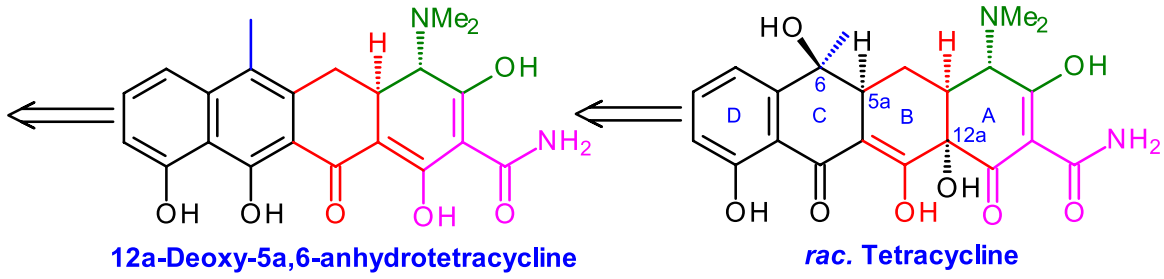


<smiles>C=C/C=C\OC(C)=O</smiles>

Juglone<smiles>CO[C@H]1C=CC[C@H]2[C@@H](O)c3c(OCc4ccccc4)cccc3[C@H](O)[C@H]12</smiles><smiles>C[C@]12CC=C[C@@H](O)[C@H]1C(O)c1c(OCc3ccccc3)cccc1[C@@H]2O</smiles>

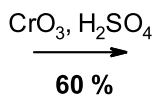<smiles>C[C@]12CC=CC(O)=C1C(=O)c1c(OCc3ccccc3)cccc1[C@@H]2O</smiles><smiles>CCOC(=O)CC(C)[N+](=O)[O-]</smiles><smiles>CCOC(=O)[C@H](C1CC(O)=C2C(=O)c3c(OCc4ccccc4)cccc3[C@@H](O)[C@]2(C)C1)[N+](=O)[O-]</smiles><smiles>[CH]C1CCCC1</smiles>
rac. Shemyakin Ketone<smiles>CCOC(=O)[C@H](N)[C@H]1CC(=O)c2c(c(O)c3c(Cc4ccccc4)cccc3c2C)C1</smiles><smiles>CCOC(=O)N1C(=O)c2ccccc2C1=O</smiles><smiles>CCOC(=O)[C@H](C)[C@H]1CC(=O)c2c(c(C)c3cccc(OCc4ccccc4)c3c2O)C1</smiles>

Fig. 23 First part of Shemyakin's total synthesis of racemic tetracycline 
<smiles>CCOC(=O)[C@H](Nc1ccccc1)[C@H]1CC(=O)c2c(c(C)c3cccc(OCc4ccccc4)c3c2C)C1</smiles><smiles>CCOC(=O)N1C(=O)c2ccccc2C1=O</smiles><smiles>CCOC(=O)C(C(N)=O)C(=O)OCC</smiles>

Diglyme, $140{ }^{\circ} \mathrm{C}$<smiles>CCOC(=O)/C(C(N)=O)=C(/O)[C@@H](c1ccccc1)[C@H]1CC(=O)c2c(c(C)c3cccc(OCc4ccccc4)c3c2OC)C1</smiles><smiles>CO[N+](C)(C)O[Na]</smiles><smiles>COc1c2c(c(C)c3c(OCc4ccccc4)cccc13)C[C@@]1(C)C(=C(O)C(C(N)=O)=C(O)[C@H]1NOc1ccccc1C(=O)O)C2=O</smiles><smiles>Cc1c2c(c(O)c3c(O)cccc13)C(=O)C1=C(O)C(C(N)=O)=C(O)[C@H](N(C)C)[C@H]1C2</smiles>
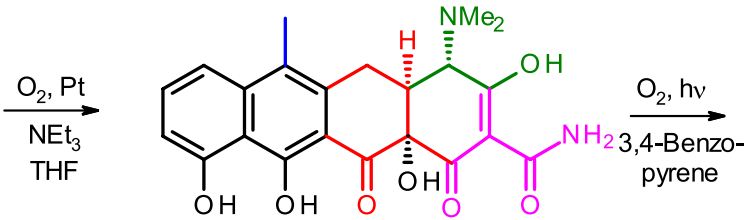

rac. 12a-Deoxy-5a,6-anhydrotetracycline<smiles>CN(C)[C@H]1C(O)=C(C(N)=O)C(=O)[C@]2(O)C(=O)C3=C(C[C@H]12)[C@@](C)(O)c1cccc(O)c1C3=O</smiles>

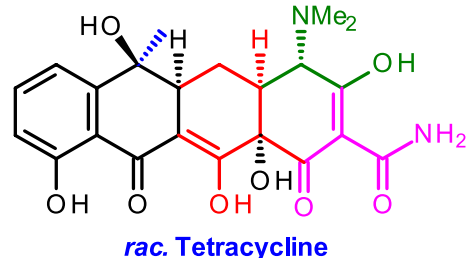

Fig. 24 Second part of Shemyakin's total synthesis of racemic tetracycline

\section{Muxfeldt's synthesis of racemic oxytetracycline}

The first synthesis of racemic oxytetracycline was accomplished by Hans Muxfeldt, originating from the German island of Fehmarn, who pursued a career at the University of Wisconsin and Cornell University in Ithaka, New York. Muxfeldt had investigated the tetracyclines since the early 1960s. At Cornell University, where he worked since 1966, he finally tackled the challenge of synthesizing oxytetracycline, which stood out because of its problematic pattern of substitution at positions 5 and 6 , a challenge from which even Woodward and Shemyakin shied from. Muxfeldt gained international acclaim when he succeeded in finally synthesizing oxytetracycline in 1968 (Fig. 25) [90-92].

During the structure determination of oxytetracycline, Woodward had noted the lability of the compound towards acids, bases, and alkylating agents such as methyl iodide. Aside from these fragmentations, proclivity to subtle

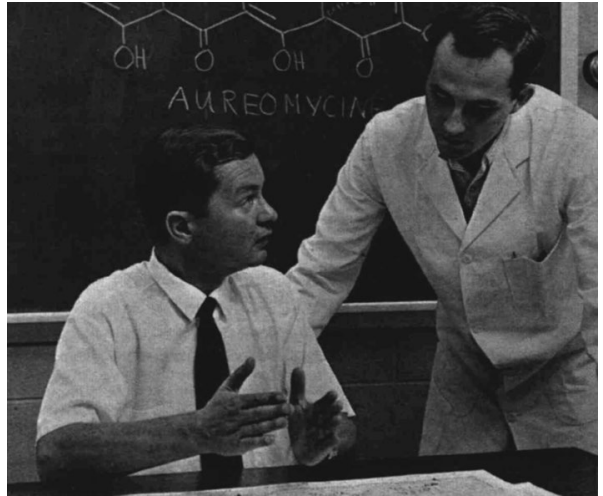

Fig. 25 In the early 1970s, Hans Muxfeldt (1927-1974), sitting at the table, was appointed at the University of Stuttgart, where in 1974, at the age of just 47 passed away tragically because of a cerebral hemorrhage [93]. His research group in Stuttgart was continued by his then postdoctoral fellow Günter Helmchen (๑) The Cornell Daily Sun 86, 6, 17 September 1969) 
structural changes were also noted. Oxytetracycline epimerizes rapidly at position 4 , for example, in the presence of an aqueous acidic buffer solution (Figs. 26, 27, 28) (Lit. cited in [90]).

The first complete publication of the synthesis of oxytetracyclines by Muxfeldt appeared in 1968, and his final works were published by his group in 1979 [90].

Starting material is, as in Shemyakin's synthesis of tetracycline, juglone, which is initially esterified and then reacted in a Diels-Alder reaction with acetoxybutadiene with inverse regioselectivity yielding the corresponding anthraquinone derivative. A stereoselective Grignard reaction and formation of a ketal with the syn-hydroxyl groups yield the starting material for the osmium tetroxide-catalyzed dihydroxylation. After cleavage of the diol with lead tetraacetate a crystalline dialdehyde is obtained, which cyclizes in a Mannich reaction and subsequently is cleaved by ozonolysis. Further breakdown in a mix of dichloromethane and aqueous sodium carbonate yields a monoaldehyde, which forms an enamine with piperidine, whose phenolic group is etherified by methoxymethyl chloride. Release of the aldehyde group yields the starting material for the further construction of the AB ring system (Fig. 29).

In the second part of the synthesis, the aldehyde is condensed with a thiazolinone and is reacted with the lithium salt of 3-oxoglutaramide. Here the A ring closes to form a dihydro resorcinol derivative. Performing the reaction in the presence of strong bases like potassium or lithium $t$-butanolate leads also to the formation of the $\mathrm{B}$ ring and the tetracycle can be isolated in crystalline form. Upon cleavage of the MOM protecting group in hot acetic acid and deprotonation with sodium hydride, in the presence of oxygen and triethylphosphite, the hydroxy group in position $12 \mathrm{a}$ is introduced. The hydroxylation is not very selective. Hydroxylation at position 11a takes place with a ratio of 1:4. In the final steps of the synthesis, the thioamide is cleaved with methyl iodide and the amino group is methylated with dimethyl sulfate. Conveniently, the methylation can also be done by reductive alkylation with sodium cyanoborohydride and formaldehyde. Both NMR spectroscopy as well as a bacteriological test confirmed the structural as well as the stereochemical integrity of the total synthetic racemic
Fig. 26 Fragmentation of oxytetracycline (terramycin) in acids

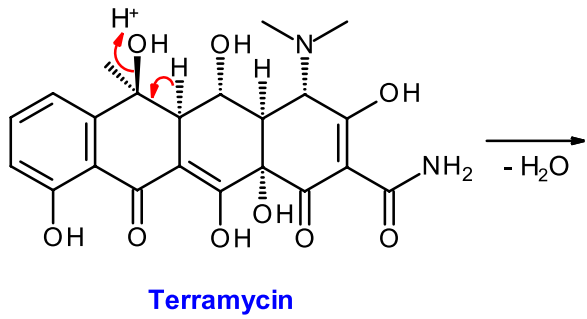<smiles></smiles>

Anhydroterramycin

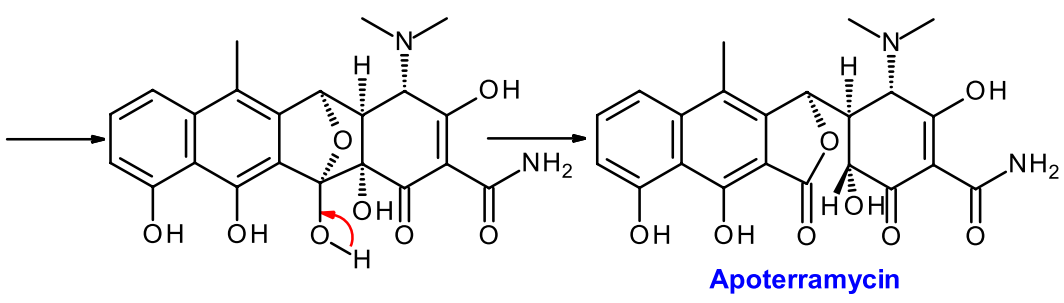


Fig. 27 Fragmentation of oxytetracycline (terramycin) in bases

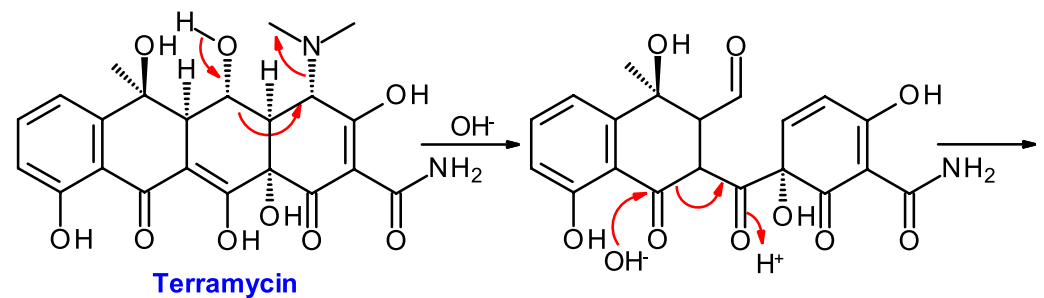

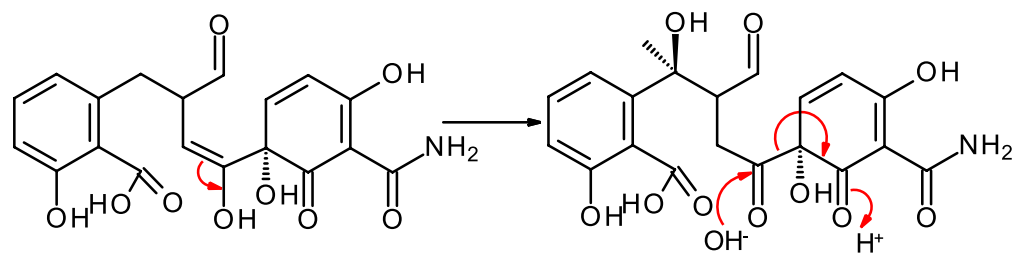<smiles>Cc1ccc(O)c(O)c1C(N)=O</smiles><smiles>C/C(=C(\CC(=O)O)C(=O)CCCO)c1ccccc1O</smiles><smiles>CC1=C(CC(=O)O)C(O)C2C3C=CC(=O)C(C(=O)O)=C3C12</smiles><smiles>CC1C(CC(=O)O)=C(O)c2ccc(O)c(C(=O)O)c21</smiles> 
Fig. 28 Fragmentation of oxytetracycline (terramycin) in the presence of alkylating agents and its epimerization in acids

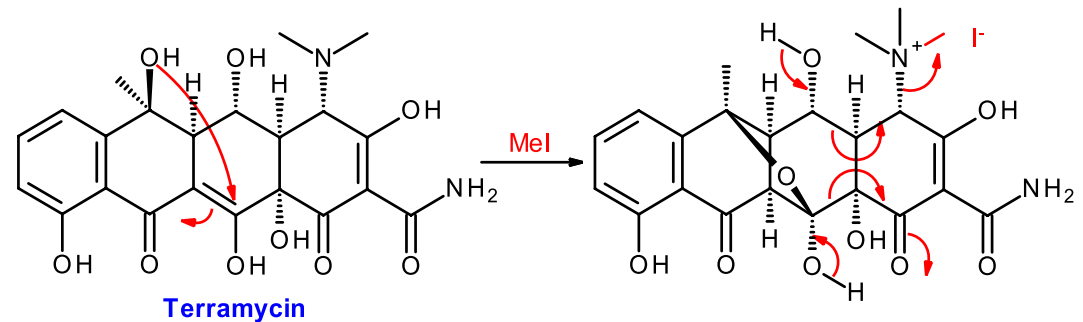

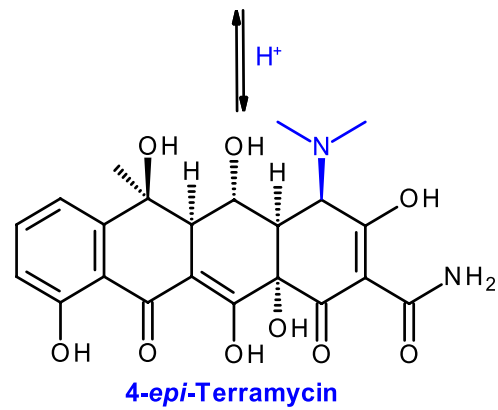<smiles>CN(C)C</smiles>

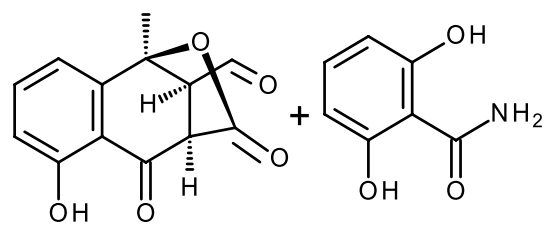<smiles>O=C1C=CC(=O)c2c(O)cccc21</smiles><smiles>C=C/C=C/OC(C)=O</smiles><smiles>CC(=O)Oc1cccc2c1C(=O)[C@@H]1CC=C[C@H](OC(C)=O)[C@@H]1C2=O</smiles>

$\mathrm{MeMgl}$

$-65^{\circ} \mathrm{C}$

$\underset{\mathrm{NaOH}}{\mathrm{NaO}}$

$84 \%$

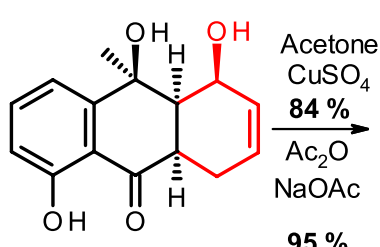<smiles>CC(=O)Oc1cccc2c1C(=O)[C@@H]1CC=C[C@@H]3OC(C)(C)O[C@@]23C1</smiles>

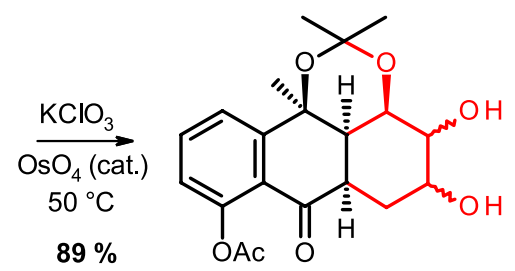

$\frac{\mathrm{Pb}(\mathrm{OAc})_{4}}{40{ }^{\circ} \mathrm{C}}$<smiles>CC(=O)Oc1cccc2c1[C@]1(C)OC(C)(C)O[C@@H](C(=O)C2)[C@H]1CC=O</smiles>

$\mathrm{DBU}, \mathrm{AcOH}$

Piperidine

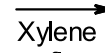

reflux

$52 \%$ (2 steps)<smiles>CC(=O)Oc1cccc2c1C(=O)[C@@H]1C(C=O)=C[C@@H]3OC(C)(C)O[C@]23[C@@H]1C</smiles>

$\underset{\mathrm{H}_{2} \mathrm{O}}{\stackrel{-50}{\mathrm{O}_{3}}}$

$68 \%$<smiles>CC(=O)Oc1cccc2c1C(=O)[C@H]1[C@H](C=O)OC(C)(C)O[C@@]2(C)[C@@H]1C(=O)C=O</smiles>

$\mathrm{CH}_{2} \mathrm{Cl}_{2}: 0,5 \mathrm{~N} \mathrm{Na}_{2} \mathrm{CO}_{3}$

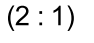

$85 \%$<smiles>CC1(C)O[C@]2(C)c3cccc(O)c3C(=O)C(C)(C)O[C@H](C=O)[C@@]2(C)O1</smiles>

Piperidine

$\stackrel{91 \%}{\stackrel{\mathrm{NaH}}{\longrightarrow}}$

$\mathrm{MOMCl}$

$90 \%$<smiles>COc1cccc2c1C(=O)C[C@]1(C)/C(=C/N3CCCCC3)OC(C)(C)O[C@@]21C</smiles>

$\underset{70-80 \%}{\stackrel{\text { silica gel }}{\longrightarrow}}$<smiles>COc1cccc2c1C(=O)C[C@]1(C)OC(C)(C)O[C@@H]2C1C=O</smiles>

Fig. 29 First part of Muxfeldt's total synthesis of racemic oxytetracycline 


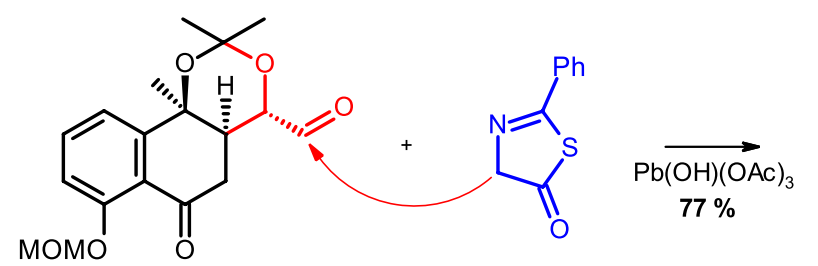

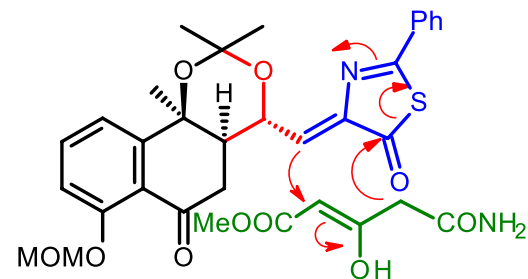

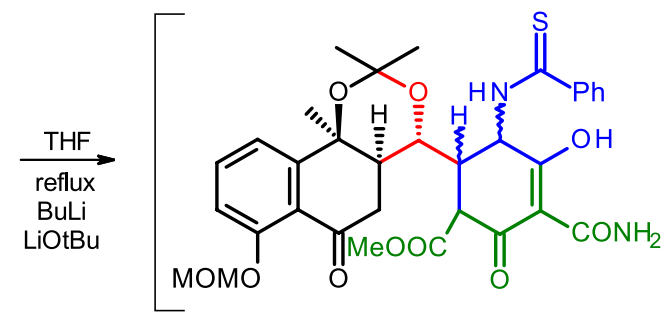<smiles>COc1cccc2c1C(=O)[C@H]1OC(C)(C)O[C@H](C23OC(C)(C)O3)[C@]2(C)C(=C1O)C(=O)C(C(N)=O)=C(O)[C@@H]2NC(=S)c1ccccc1</smiles>

$\mathrm{AcOH}: \mathrm{H}_{2} \mathrm{O}$

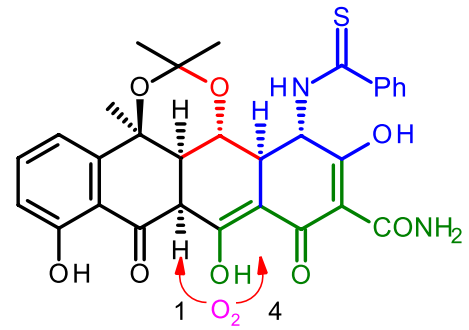

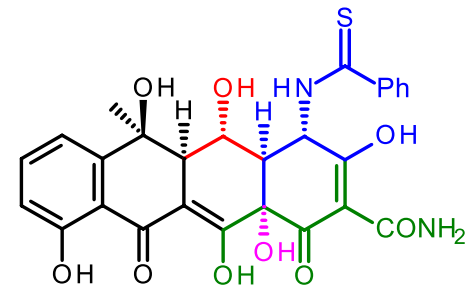<smiles>C[C@@]12C(=C(O)[C@@]3(C)C1=C(O)[C@@]1(O)C(=O)C(C(N)=O)=C(O)[C@H](N)[C@H]1[C@@H]3O)C(=O)c1c(O)cccc12</smiles>

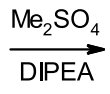<smiles>COC(=O)C1=C(O)[C@@]2(O)C(=O)C(C(N)=O)=C(O)[C@@H](N(C)C)[C@H]2[C@@H](O)[C@@]2(O)c3cccc(O)c3C(=O)C12O</smiles>

Fig. 30 Second part of Muxfeldt's total synthesis of racemic oxytetracycline

oxytetracycline compared to the fermentative enantiopure product (Fig. 30).

\section{Tatsuta's synthesis of enantiopure (-)-tetracycline}

The first synthesis of enantiopure (-)-tetracycline originates from Kuniaki Tatsuta from Wasada University in Tokyo from 2000 [94]. It is a diastereoselective synthesis based on D-glucosamine (Fig. 31).

Key steps in the construction of the framework are a Ferrier carbocyclization (by Robert John Ferrier (1932-2013), Scottish/New Zealand chemist) followed by a Diels-Alder reaction with butadienyl trimethylsilyl ether and a Michael-Dieckmann-type condensation in which the tetracycle is formed. After oxidation of the 1,3-diol at the A ring, the hydroxyl groups in positions $12 \mathrm{a}$ and 6 are introduced in further oxidation steps.

The adequately protected D-glucosamine is initially oxidized (Pfitzner-Moffatt oxidation). This is followed by a
Wittig reaction, desilylation, and the formation of the corresponding selenide. Hydroboration of the olefin with oxidative workup results in not only the alcohol but in this event the selenide is also eliminated to provide an exo-cyclic double bond. Following protection of the alcohol functionality, mercury(II) chloride catalyzes the Ferrier carbocyclization. After elimination of water and epimerization of the $\mathrm{BnOCH}_{2}$ group, a regio- and stereoselective Diels-Alder reaction follows, which forms a labile intermediate that is immediately oxidized. The domino Michael-Dieckmann-type condensation with the corresponding isobenzofuranone yields the tetracyclic scaffold that is aromatized with thionyl chloride in good yields. The benzyl-containing protecting groups are selectively removed by boron tribromide and subsequent hydrogenation. The amino group is Boc-protected, and the enol is converted to the methylether (Fig. 32).

In the second part of the synthesis, Tatsuta encountered an unforeseen difficulty in his synthesis. The direct oxidation of the 1,3-diol of ring A failed, and thus required five steps 


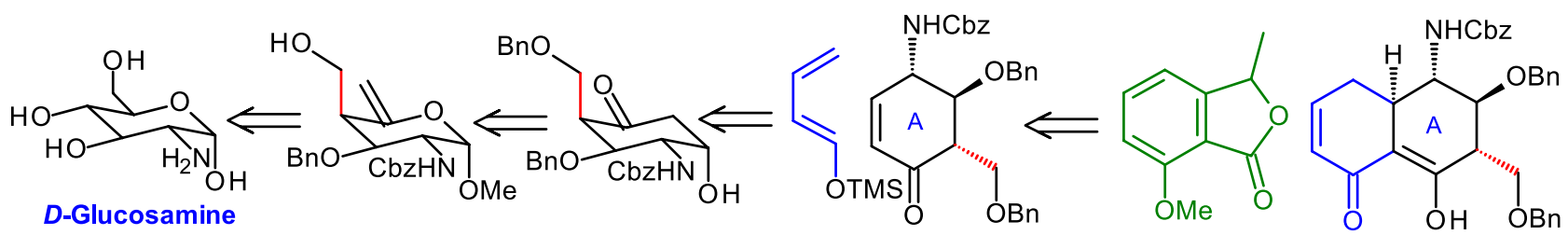<smiles>CC(C)(C)OC(=O)c1ccccc1</smiles><smiles>C[C@H]1C2=C(O)[C@@H](O)[C@@H](N(C)C)C[C@@H]2C(=O)c2c(O)cccc21</smiles>

(-)-Tetracycline

Fig. 31 Retrosynthetic considerations of Tatsuda's synthesis of enantiopure (-)-tetracycline. Elegantly, Tatsuta used the sugar to build the highly functionalized A ring at the beginning of the total synthesis
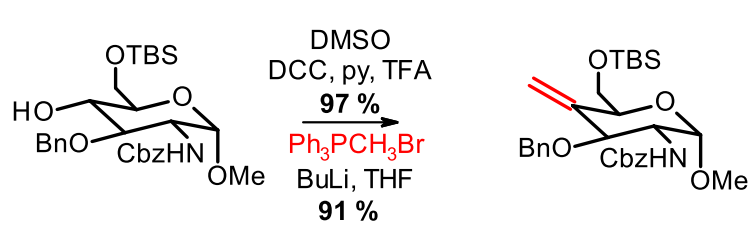

$91 \%$

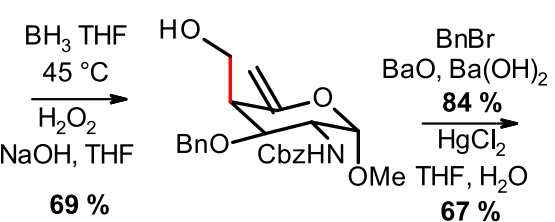

$69 \%$

$67 \%$

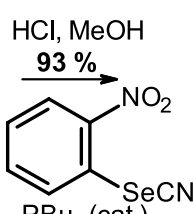

$\mathrm{PBu}_{3}$ (cat.)

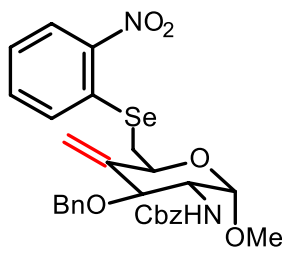

$90 \%$<smiles>O=C1C=C[C@@H](N=C(O)c2ccccc2)[C@H](COCc2ccccc2)C1=O</smiles><smiles>CCOc1ccccc1OC</smiles>

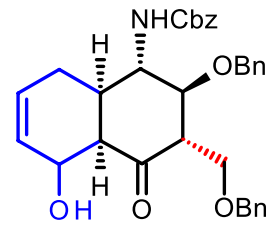<smiles>O=C[AsH3]</smiles>

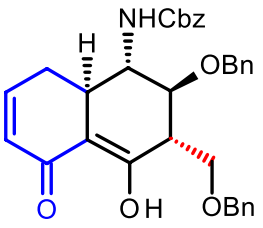<smiles>CC(C)COc1cccc2c1C(=O)OC2C</smiles>

$80 \%$

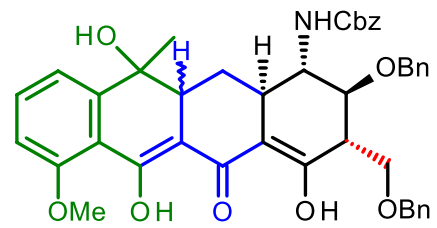

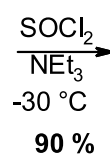<smiles>COc1cccc2c(C)c3c(c(O)c12)C(=O)C1=C(O)[C@H](COCc2ccccc2)[C@H](C(=O)c2ccccc2)[C@H](NC=[18O])[C@H]1C3</smiles>

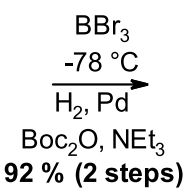<smiles>COc1cccc2c(C)c3c(c(O)c12)C(=O)C1=C(O)[C@H](CO)[C@H](O)[C@H](N)[C@H]1C[C@@H]3N[13C](=O)c1ccccc1</smiles>

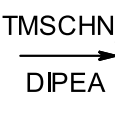
$72 \%$<smiles>COC1=C2C(=O)c3c(c(C)c4cccc(OC)c4c3O)C[C@H]2[C@@H](N)[C@H](O)[C@@H](CO)C1(C)C(=O)O</smiles>

Fig. 32 The first part of Tatsuta's synthesis of enantiopure (-)-tetracycline 
and finally the sequential oxidation with the Dess-Martin reagent.

Notable is the stereoselective $\alpha$-facial epoxidation in position $12 \mathrm{a}$ with dimethyldioxirane. In the next steps of the synthesis the aldehyde function is converted to the amide and the amino group is methylated twice (Eschweiler-Clarke methylation). Finally, photooxidation yields a hydroperoxide at position 6 , which is reduced to (-)-tetracycline over platinum black with hydrogen (Figs. 33 and 34).<smiles>COC(=O)N[C@@H]1[C@@H]2Cc3c(c(O)c4c(OC)cccc4c3C)C(=O)C2=C(OC)[C@H](CO)[C@H]1O</smiles>

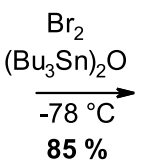

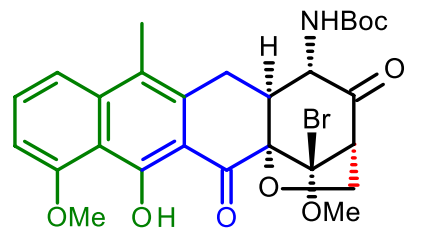<smiles>COC1=C2C(=O)c3c(c(C)c4cccc(OC)c4c3O)C[C@H]2[C@H](N)C(=O)/C1=C/O</smiles><smiles>COC(=O)N[C@H]1C(O)=C(C#N)C(=O)[C@@]2(O)C(=O)c3c(c(C)c4cccc(OC)c4c3O)C[C@H]12</smiles><smiles>Cc1c2c(c(O)c3c(O)cccc13)C(=O)[C@@]1(O)C(=O)C(C(N)=O)=C(O)[C@H](N(C)C)[C@H]1C2</smiles>

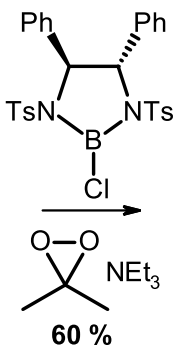

$\mathrm{H}_{3} \mathrm{PO}_{4}$ $100^{\circ} \mathrm{C}$ $\underset{\mathrm{H}_{2} \mathrm{CO}}{\stackrel{68 \%}{\longrightarrow}}$ $\mathrm{HCOOH}$ $80 \%$

$$
\mathrm{O}_{2} \mathrm{hv}_{\mathrm{v}}
$$

Tetraphenylporphyrin (cat.)

$$
\overrightarrow{\mathrm{H}_{2}, \mathrm{Pt}}
$$

$47 \%$ (2 steps)

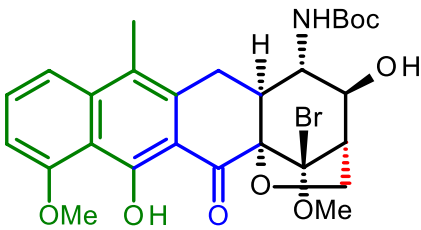

\section{$\underset{\mathrm{Dess-Martin}}{\stackrel{\mathrm{P}}{\longrightarrow}}$} $91 \%$<smiles>COC(=O)[C@H](N)C1=C(CO)C(=O)[C@H](N)[C@H]2Cc3c(c(O)c4c(OC)cccc4c3C)C(=O)[C@H]12</smiles>

\section{Dess-Martin \\ Periodinane \\ $62 \%$ \\ (2 steps)}<smiles>Cc1c2c(c(C)c3c(C)cccc13)[C@@]1(OC(=O)O)C(=O)C(C=O)=C(O)[C@@H](N)[C@@H]1C2</smiles>

$80 \%$<smiles>COc1cccc2c(C)c3c(c(O)c12)C(=O)[C@]1(O)C(=O)C(C(N)=O)=C(O)[C@H](N(C)C)[C@H]1C3</smiles><smiles>CN(C)[C@H]1C(O)=C(C(N)=O)C(=O)[C@]2(O)C(O)=C3C(=O)c4c(O)cccc4[C@@](C)(O)[C@@]3(C)C[C@H]12</smiles>

(-)-Tetracycline

Fig. 33 Second part of Tatsuta's route to enantiopure (-)-tetracycline prolonged because of an unexpected oxidation problem
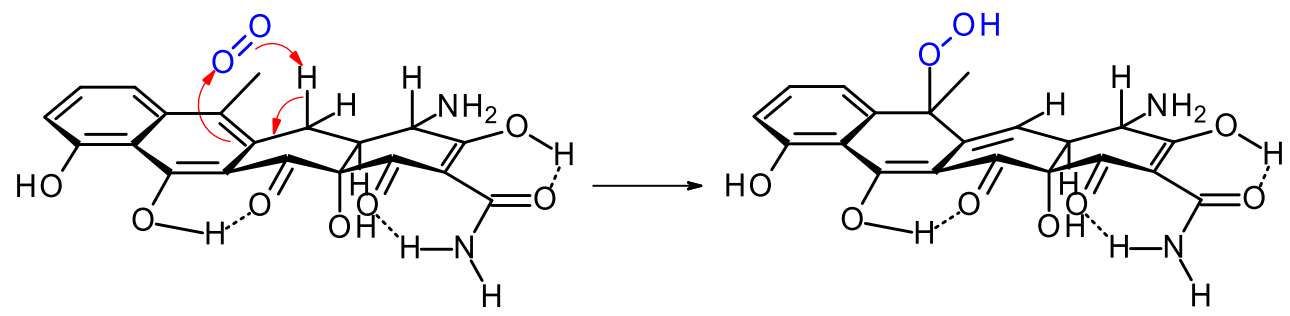

Fig. 34 Penultimate step of Tatsuta's synthesis: the oxidation with oxygen can be seen as a formal ene reaction (Schenck reaction), which as a result of steric reasons occurs only "above" the tetracycline involving the axial hydrogen at C-5, finally forming the needed diastereomer [95] 


\section{Stork's synthesis of enantiomeric ( \pm )-12a-deoxytetracycline}

In 1996, Gilbert Stork (1921-2017), at that time emeritus at Columbia University, published a remarkable synthesis of racemic 12a-deoxytetracycline, which in some respect became trendsetting for future preparation methods of tetracyclines, both in academia and industry [96]. The synthesis features a domino Dieckmann cyclization reaction for the construction of the tetracycline nucleus and probably even more importantly the use of an isoxazolidine derivative as

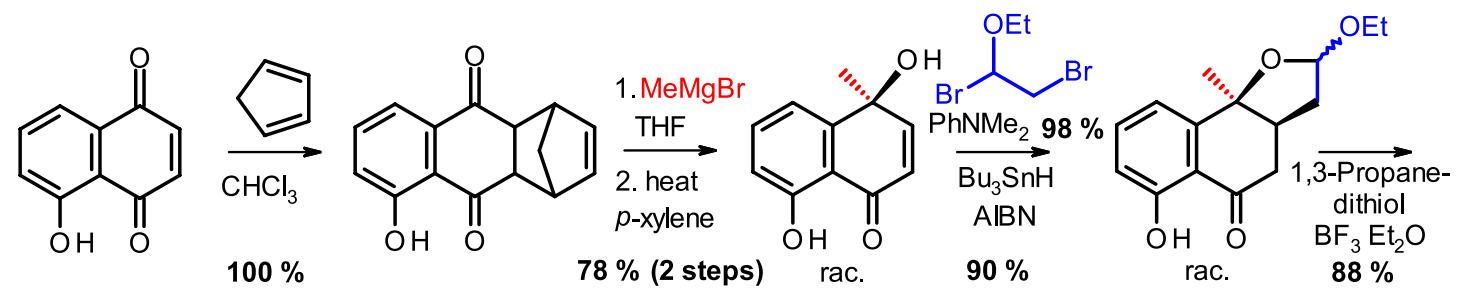

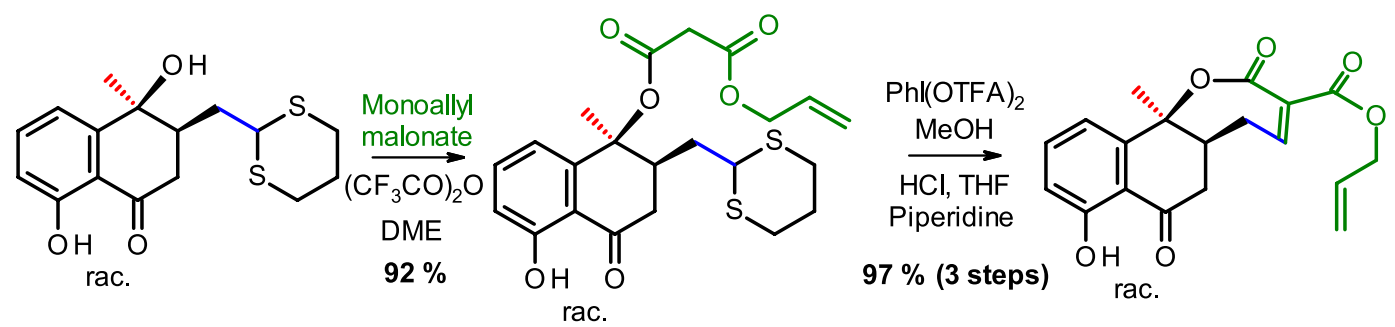

Fig. 35 The first part of Stork's synthesis of racemic 12a-deoxytetracycline leads to the formation of a precursor of the later CD ring

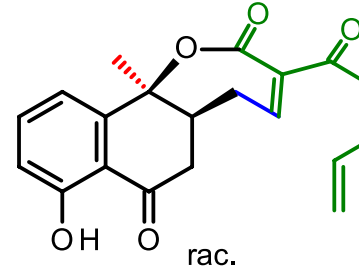<smiles>CN[C@@H](c1onc(C(=O)OC)c1C(=O)OC)[C@@H](CC(=O)OC)C[C@@H]1CC(=O)c2c(O)cccc2[C@@]1(C)O</smiles>
rac.<smiles>CN[C@H]1c2onc(Cc3ccccc3)c2C(O)=C2C(O)=C3C(=O)c4c(O)cccc4[C@@](C)(O)[C@H]3C[C@H]21</smiles>
rac.<smiles>COC(=O)c1c(OCc2ccccc2)noc1CN(C)C</smiles>

NaHMDS $\underset{\mathrm{Pd}\left(\mathrm{PPh}_{3}\right)_{4}}{\stackrel{\mathrm{THF}}{\longrightarrow}}$ Ethylhexanoic acid EtOAc, DCM

$95 \%$ (2 steps)

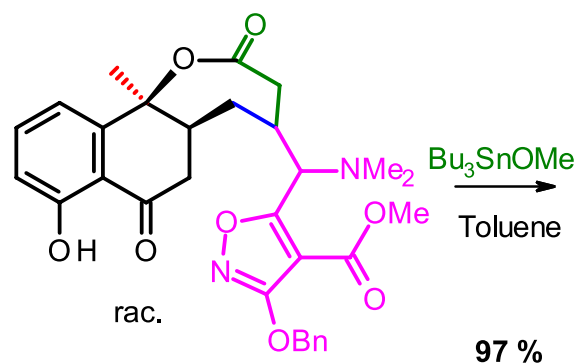

$97 \%$

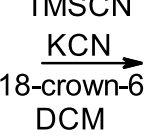

$\mathrm{H}_{2}, \stackrel{\text { Pd-black }}{\longrightarrow}$

$94 \%$

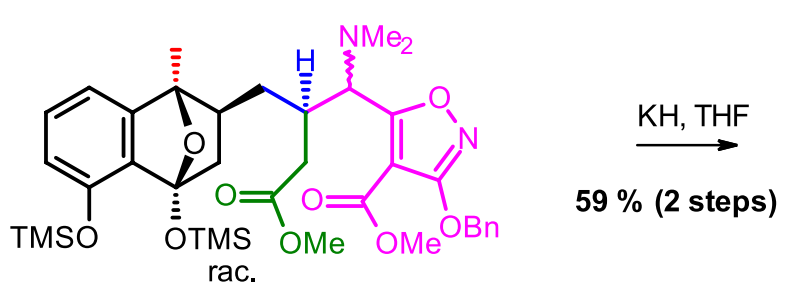

rac.<smiles>CNC(=O)C1=C(O)[C@H](N(C)C)[C@]2(C)C[C@H]3C(=C(O)C1=C2O)C(=O)c1c(O)cccc1[C@@]3(C)O</smiles>

Fig. 36 The second part of Stork's synthesis of racemic 12a-deoxytetracycline is focused on the introduction of the dense functionality at the A ring and the construction of the tetracycle by domino Dieckmann cyclization 
a precursor for the vinylogous carbamic acid at the A ring [97].

As in Muxfeldt's synthesis the starting material is juglone, which is reacted with cyclopentadiene in the first step, in order to avoid 1,4-addition of the following Grignard reaction. This proceeds with high regioselectivity. After removal of the protecting group by retro-Diels-Alder reaction, the tertiary alcohol is used to direct the stereochemistry of the following radical-mediated haloacetal cyclization. The subsequent steps comprise the formation of a thioacetal, esterification of the liberated alcohol with monoallyl malonate, and after oxidative cleavage of the thioactal an intramolecular Knoevenagel condensation (Fig. 35).

By Michael addition with an elaborated isoxazole the main part of what later will become the A ring is introduced.
After Pd-catalyzed removal of the allyl ester, the sevenmembered lactone is cleaved with tributyl(methoxy)stannane. In preceding syntheses Stork had struggled and finally failed in constructing the tetracycline nucleus from the $\mathrm{BCD}$ fragment. Therefore, he decided to protect the $\mathrm{C}$ ring ketone as a siloxyketal by the use of cyanotrimethylsilane, a catalytic amount of potassium cyanide, and 18-crown-6, in advance to the domino Dieckmann cyclization. Hydrogenolysis finally delivered racemic 12 a-deoxytetracycline after 16 steps and in $28.2 \%$ overall yield (Fig. 36 ).

\section{Myers' synthesis of enantiomeric (-)-doxycycline}

In the year 2005, Andrew Myers from Harvard University in Cambridge, Massachusetts, described in a notable article the
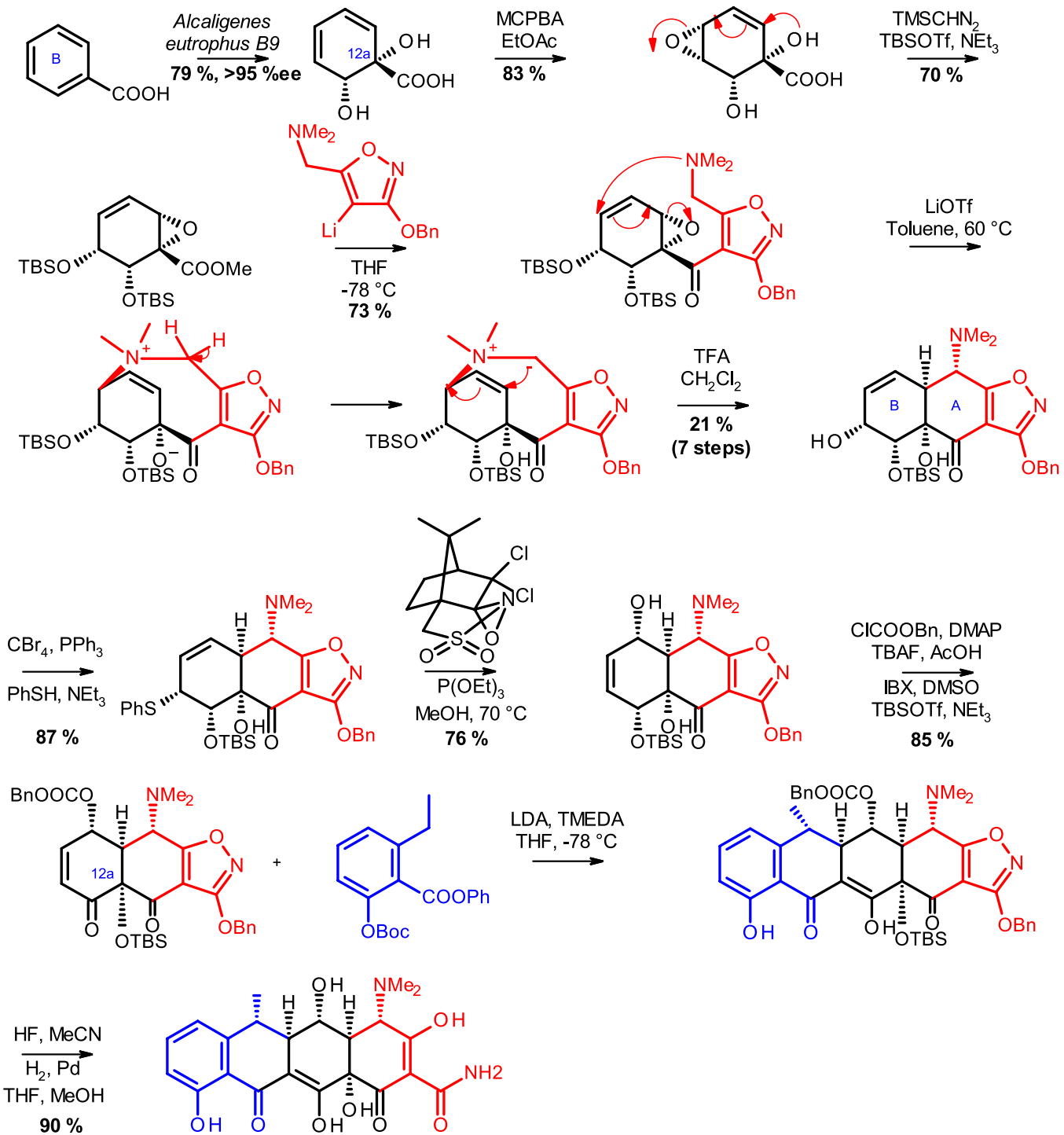

(-)-Doxycycline

Fig. 37 Andrew Myers' synthesis of enantiomeric (-)-doxycycline. It is obtained in 18 steps with an overall yield of $8.3 \%$ 
enantioselective synthesis of a group of tetracyclines, which are built in a modular way with an $\mathrm{AB}$ and different $\mathrm{D}$ ring fragments to yield a series of analogues of (-)-doxycycline in 14 to 18 steps in yields of 5-8\% [98-100].

In the very first step of the total synthesis, Myers installs the often problematic hydroxyl group in position 12a of the tetracycline scaffold by a microbial dihydroxylation of benzoic acid with a mutant Alcaligenes eutrophus (today: Cupriavidus necator of the family Burkholderiaceae) around which the $\mathrm{AB}$ fragment is built. A hydroxy-guided $\alpha$-facial epoxidation is followed by an esterification of the carboxylic acid with trimethylsilyldiazomethane and a silylation of the hydroxy groups, which is accompanied by a rearrangement of the epoxide. Inspired by tetracycline syntheses from Gilbert Stork [96, 97], Myers used a similar isoxazole to build the A ring. The reaction initially yields a ketone, which upon heating in the presence of $5 \mathrm{~mol} \%$ lithium triflate cyclizes at $60{ }^{\circ} \mathrm{C}$. With trifluoroacetic acid, the allylic silylether can be selectively cleaved.

From a mechanistic point of view, the ring closure to the A ring is achieved by an $\mathrm{S}_{\mathrm{N}} 2^{\prime}$ attack of the dimethylamine group, which forms an $\mathrm{N}$-ylide, which in turn undergoes a [2,3]-sigmatropic rearrangement similar to a Sommelet-Hauser reaction.

In the next step, the allylic hydroxy group is replaced by a thiophenyl group under a formal retention of configuration by a bromide formed by an Appel reaction. This is then oxidized to the sulfoxide with high diastereoselectivity. A Mislow-Evans rearrangement yields the necessary allyl alcohol, which is protected as the benzyl carbonate. The TBS protecting group is cleaved off, the allylic alcohol is oxidized with 2-iodoxybenzoic acid, and the hydroxy group at position 12a is protected. The tetracycline scaffold is obtained by a Michael-Dieckmann condensation with the corresponding benzoic acid derivative. In the remaining steps, all protecting groups are cleaved off and finally the vinylogous carbamic acid is released by hydrogenation (Fig. 37).

The construction of the tetracycline scaffold by Michael-Dieckmann condensation became key for the synthesis of numerous analogues. By this methodology, Myers succeeded in not only synthesizing (-)-doxycycline but also tetracycline [101], novel 7-, 9-azatetracyclines [98], and pentacyclines [99]. Eventually, his approach inspired innovative industrial total syntheses (Fig. 38).

\section{Industrial synthesis}

The six illustrative syntheses chosen, from Woodward to Myers, impressively display not only the methodical progress and the expansion of the synthetic repertoire of preparative organic chemistry over the last 50 years but they also highlight the elegance with which structurally and functionally challenging molecules are built today. Nonetheless, as a result of economic reasons, even the newest total syntheses struggle to compete with the simpler fermentative methods and partial syntheses of tetracyclines.

Almost all marketable tetracyclines are produced by partial syntheses from chlortetracycline, tetracycline, oxytetracycline, and demeclocycline. These are traditionally produced by submersion culture and more recently by solid phase fermentation. Carbon sources are waste materials from agriculture like sweet potatoes, corncobs, peanut shells, cassava, or pineapple peels. The compounds are extracted with ethyl acetate, acetonitrile, or methanolic trichloroacetic acid and then purified by crystallization (Fig. 39) [102, 103].

For an efficient fermentative production at industrial scale, the delineation of the biosynthesis is indispensable. This was ultimately determined by the complete sequencing of the corresponding gene cluster from Streptomyces rimosus, metabolism studies with labeled substances, and biosynthetic experiments with knockout mutants.

\section{Biosynthesis}

The tetracyclines are derived by the polyketide biosynthesis pathway, in which initially nonaketidamide is built from malonamoyl-CoA, then aromatized stepwise, and finally
Fig. 38 Myers' novel 7-, 9-azatetracyclines and pentacyclines<smiles>[3H]c1cccc2c1CC1C[C@]3(C)[C@@H](N(C)C)C(O)=C(C(N)=O)C(=O)[C@@]3(O)C(O)=C1C2=O</smiles>

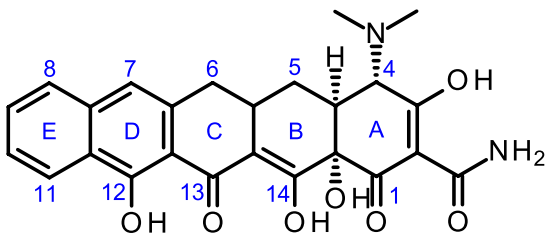<smiles>Cc1cc2c(c(=O)[nH]1)C(=O)C1=C(O)[C@]3(O)C(=O)C(C(N)=O)=C(O)[C@H](N(C)C)[C@]3(C)CC1C2</smiles><smiles>CN(C)[C@H]1C(O)=C(C(N)=O)C(=O)[C@]2(O)C(O)=C3C(=O)c4c(c(O)c5ccc(CN)cc5c4O)C3C[C@]12C</smiles> 
Fig. 39 Major tetracycline fermentation products. They are active ingredients but also starting materials for partial syntheses<smiles>CN(C)[C@H]1C(O)=C(C(N)=O)C(=O)[C@]2(O)C(O)=C3C(=O)c4c(O)ccc(Cl)c4[C@@](C)(O)[C@@]3(C)C[C@H]12</smiles>

Streptomyces aureofaciens<smiles>CN(C)[C@H]1C(O)=C(C(N)=O)C(=O)[C@]2(O)C(O)=C3C(=O)c4c(O)cccc4[C@@H](O)[C@@]3(C)C[C@H]12</smiles><smiles>CN(C)[C@H]1C(O)=C(C(N)=O)C(=O)[C@]2(O)C(O)=C3C(=O)c4c(O)cccc4[C@@](C)(O)[C@@]3(C)[C@H](O)[C@H]12</smiles><smiles>CN(C)[C@H]1C(O)=C(C(N)=O)C(=O)[C@]2(O)C(O)=C3C(=O)c4c(O)ccc(Cl)c4C(O)[C@@H]3C[C@H]12</smiles>

mutant of Streptomyces aureofaciens selectively hydroxylated and oxygenated by oxygenases [104-107]. Prior to the first ring closure, the keto group in position 9 is reduced. The aromatization then occurs by aldol condensation and elimination of water. The product of the complete aromatization is pretetramide, which is methylated at position 6 of the tetracycline scaffold with $S$-adenosyl methionine (SAME) and then hydroxylated and oxidized at positions C-12a and C-4. Following "reductive amination" at position 4, the amino group is also methylated twice with $S$-adenosyl methionine. By hydroxylating at C-6 and hydrogenation at position $5 \mathrm{a}, 11 \mathrm{a}$, tetracycline is obtained [108].
Branching at different positions of the biosynthetic pathway, other fermentation products are also formed (Figs. 40, 41, 42). Furthermore, genetically engineered strains of Streptomyces aureofaciens have been developed which produce chlortetracycline from tetracycline with a remarkable final titer of almost $26 \mathrm{~g} / 1$ [109].

\section{Amide-functionalized tetracyclines}

A group of partial synthesized tetracyclines, like clomocycline, rolitetracycline, and lymecycline, are derivatives of tetracycline and chlortetracycline, which are functionalized 
Fig. 40 The biosynthesis of tetracyclines. OxyA, OxyB, OxyC, OxyD, OxyJ, OxyK, OxyN, OxyF, OxyL, OxyQ, OxyT, OxyS, and OxyR are the enzymes involved in the biosynthesis of tetracycline<smiles></smiles>

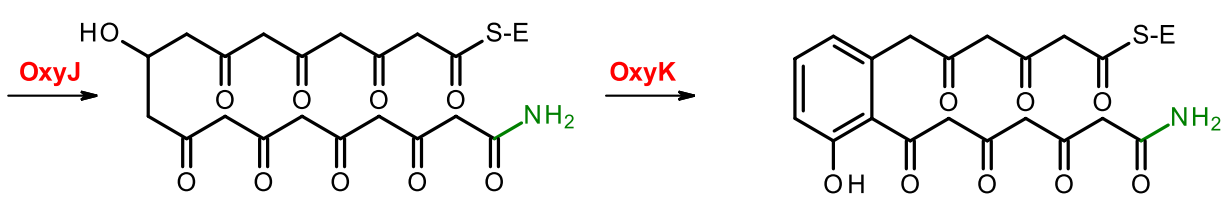

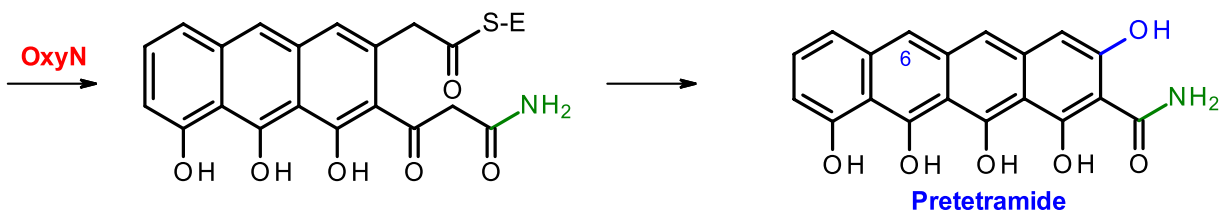

$\underset{\mathrm{SAME}}{\stackrel{\mathrm{OxyF}}{\longrightarrow}}$<smiles>Cc1c2cccc(O)c2c(O)c2c(O)c3c(O)c(C(N)=O)c(O)cc3cc12</smiles>

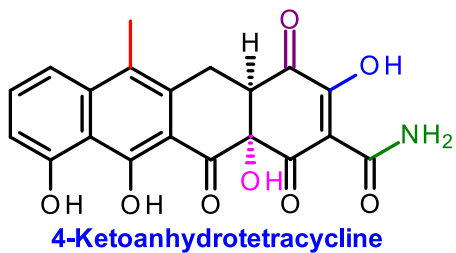

OxyQ<smiles>Cc1c2c(c(O)c3c(O)cccc13)C(=O)[C@@]1(O)C(=O)C(C(N)=O)=C(O)[C@H](N)[C@H]1C2</smiles><smiles>Cc1c2c(c(O)c3c(O)cccc13)C(=O)[C@@]1(O)C(=O)C(C(N)=O)=C(O)[C@H](N(C)C)[C@]1(C)C2</smiles>

$\stackrel{\text { Oxys }}{\longrightarrow}$

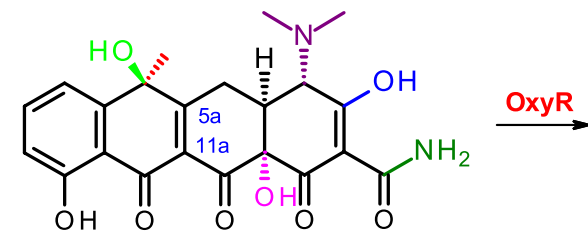

5a,11a-Dehydrotetracycline<smiles>CN(C)[C@H]1C(O)=C(C(N)=O)C(=O)[C@]2(O)C(O)=C3C(=O)c4c(O)cccc4[C@@]4(O)CCCCC34[C@@H]1C[C@H]2Cl</smiles>

Fig. 41 Oxytetracycline is obtained by hydroxylation of 5a,11a-dehydrotetracycline at C-5<smiles>CN(C)[C@H]1C(O)=C(C(N)=O)C(=O)[C@]2(O)C(=O)C3=C(C[C@]12C)[C@@](C)(O)c1cccc(O)c1C3=O</smiles>

5a,11a-Dehydrotetracycline<smiles>CN(C)[C@H]1C(O)=C(C(N)=O)C(=O)[C@]2(O)C(=O)C3=C([C@H](O)[C@]12C)[C@@](C)(O)c1cccc(O)c1C3=O</smiles>

5a,11a-Dehydrooxytetracycline

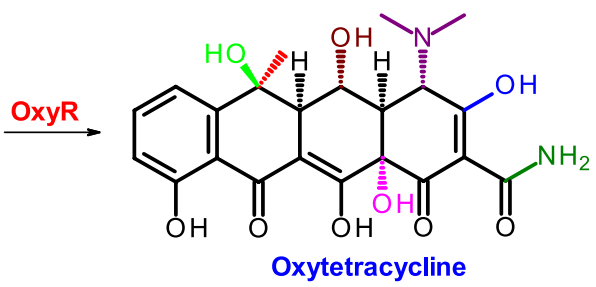


Fig. 42 The biosynthesis of chlortetracycline branches off at 4-ketoanhydrotetracycline, which initially is chlorinated at position 7 (Halogenase: 4-ket oanhydrotetracycline: $\mathrm{FADH}_{2}$ oxidoreductase) before the synthetic sequence continues like with tetracycline [110]<smiles></smiles><smiles>CCC[SeH]</smiles><smiles>Cc1c2c(c(O)c3c(O)ccc(Cl)c13)C(=O)[C@@]1(O)C(=O)C(C(N)=O)=C(O)C(=O)[C@H]1C2</smiles>
4-Ketoanhydrochlortetracycline<smiles>Cc1c2c(c(O)c3c(O)ccc(Cl)c13)C(=O)[C@@]1(O)C(=O)C(C(N)=O)=C(O)[C@@H](N)[C@H]1C2</smiles><smiles>Cc1c2c(c(O)c3c(O)ccc(Cl)c13)C(=O)[C@@]1(O)C(=O)C(C(N)=O)=C(O)[C@H](N(C)C)[C@H]1C2</smiles><smiles>CN(C)[C@H]1C(O)=C(C(N)=O)C(=O)[C@@]2(O)C(=O)C3=C(C[C@]12C)[C@@](C)(O)c1c(Cl)ccc(O)c1C3=O</smiles>

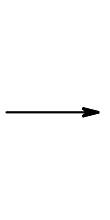

at the amide group with formaldehyde and optionally with pyrrolidine or lysine (Fig. 43) [111-114].

\section{Doxycycline}

The synthesis of doxycycline by Pfizer begins with oxytetracycline $[115,116]$. The central intermediary product is metacycline, which is obtained by treatment of oxytetracycline with $N$-chlorosuccinimide, dehydration in pure hydrogen fluoride, and then reductive dehalogenation with sodium dithionite. Although the reduction of the exo-cyclic methylene group with noble metal catalysts yield a 1:1 mixture of the C- 6 epimers, the radical addition of thiophenol occurs highly selectively forming 13-(phenylmercapto) doxycycline [117]. Enantiopure doxycycline is obtained by desulfurization with Raney nickel in refluxing ethanol (Fig. 44) [118].

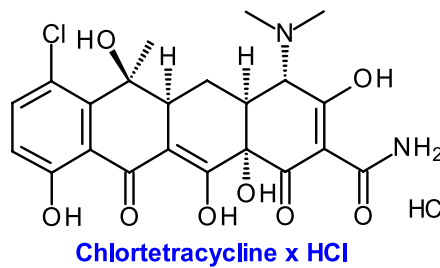

$\underset{\mathrm{H}_{2} \mathrm{O}}{\mathrm{\textrm {H } _ { 2 } \mathrm { CO }}}$
$\stackrel{\mathrm{H}}{\longrightarrow}$<smiles>CN(C)[C@H]1C(O)=C(C(=O)NCO)C(=O)[C@]2(O)C(O)=C3C(=O)c4c(O)ccc(Cl)c4[C@@H](O)[C@@]3(C)C[C@H]12</smiles><smiles>CN(C)[C@H]1C(O)=C(C(N)=O)C(=O)[C@]2(O)C(O)=C3C(=O)c4c(O)cccc4[C@@](C)(O)[C@@]3(C)C[C@H]12</smiles><smiles>CCCCC1CC2CC(CC2=O)N1O</smiles>

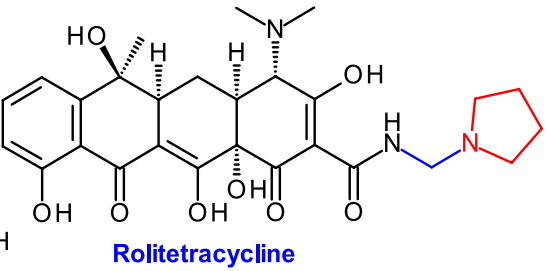

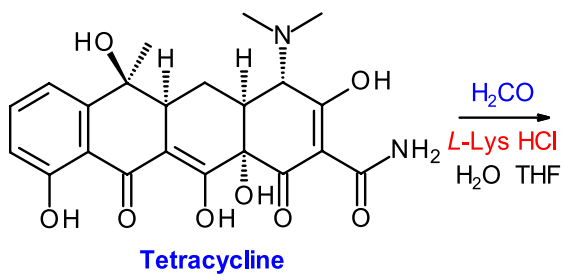<smiles>CN(C)[C@H]1C(O)=C(C(=O)NCNCCCCC(N)C(=O)O)C(=O)[C@@]2(O)C(O)=C3C(=O)c4c(O)cccc4[C@@H](O)[C@@]3(C)C[C@H]12</smiles>

Fig. 43 Examples of amide-functionalized tetracyclines 
Fig. 44 The doxycycline synthesis by Pfizer

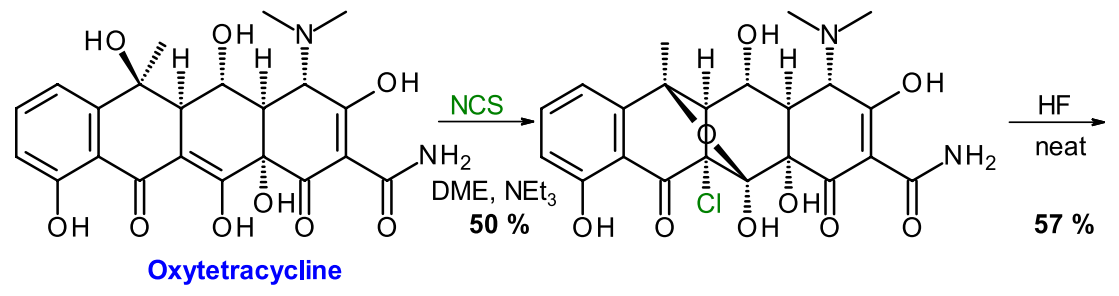

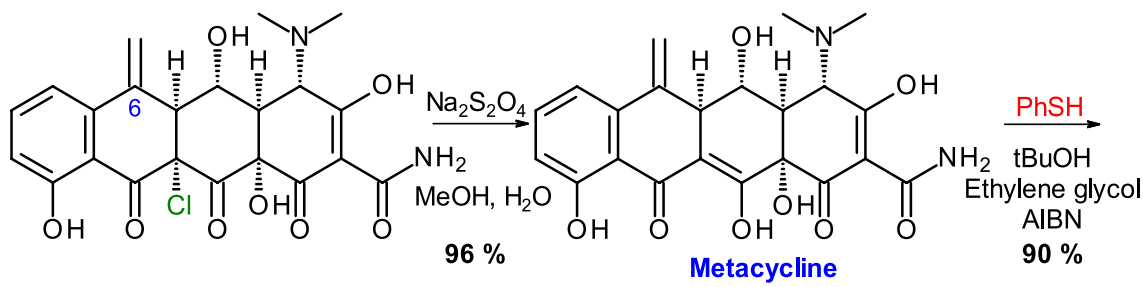

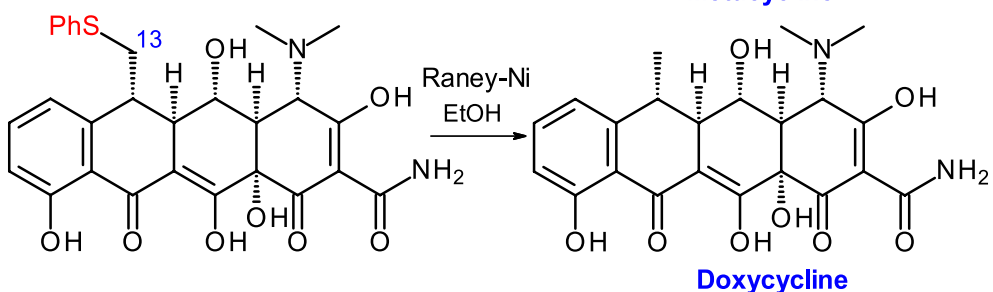

Doxycycline
In a much simpler route, Jerry Robert Daniel McCormick at Lederle synthesized doxycycline merely by hydrogenation of oxytetracycline (Fig. 45) [119].

\section{Minocycline}

The key discovery for the development of a new group of tetracyclines of the second generation was made by Charles Stephens in 1958 at Pfizer, when he recognized that the hydroxy group at the C-6 position could be reductively removed [120, 121]. The so formed 6-deoxytetracyclines were more stable than the initial compounds and also retained their broad antibacterial activity.

Jerry Robert Daniel McCormick at Lederle investigated the fermentation products of Streptomyces aureofaciens mutants and discovered demeclocycline. Demeclocycline when reductively dehalogenated under basic conditions and then dehydroxylated under acidic conditions yields sancycline [122].

Fig. 45 The doxycycline synthesis by Lederle

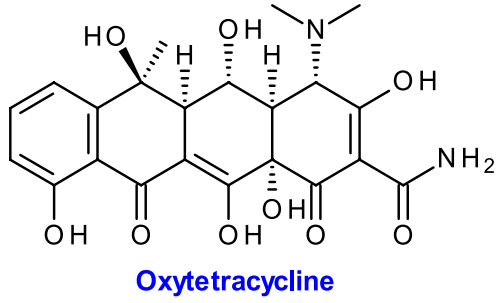

Minocycline was finally discovered in 1976 at Lederle by James Boothe and Michael Martell Jr. The nitration of sancycline practically always yields a mixture of 7- and 9-nitrosancycline in a 1:2 ratio. Nonetheless, the yield of $50 \%$ with sulfuric acid could be improved to $100 \%$ with hydrofluoric acid [123]. Both isomers could be separated by crystallization. Though 7-nitrosancycline can be directly reductively methylated to minocycline, the 9-isomer requires a longer reaction sequence (Fig. 46) [124-127].

\section{Tigecycline}

In search of newer tetracyclines which also show activity against emerging resistant strains, Francis Tally from Wyeth (formerly Lederle) modified the tetracycline scaffold at positions 7 and 9 in the 1990s, leading to the discovery of tigecycline, the first member of the third generation of tetracyclines. Phaik-Eng Sum, a process chemist at American Cyanamide, developed several syntheses, which allowed<smiles>C[C@@H]1c2cccc(O)c2C(=O)C2=C(O)[C@]3(O)C(=O)C(C(N)=O)=C(O)[C@H](N(C)C)[C@H]3[C@H](O)[C@H]21</smiles> 


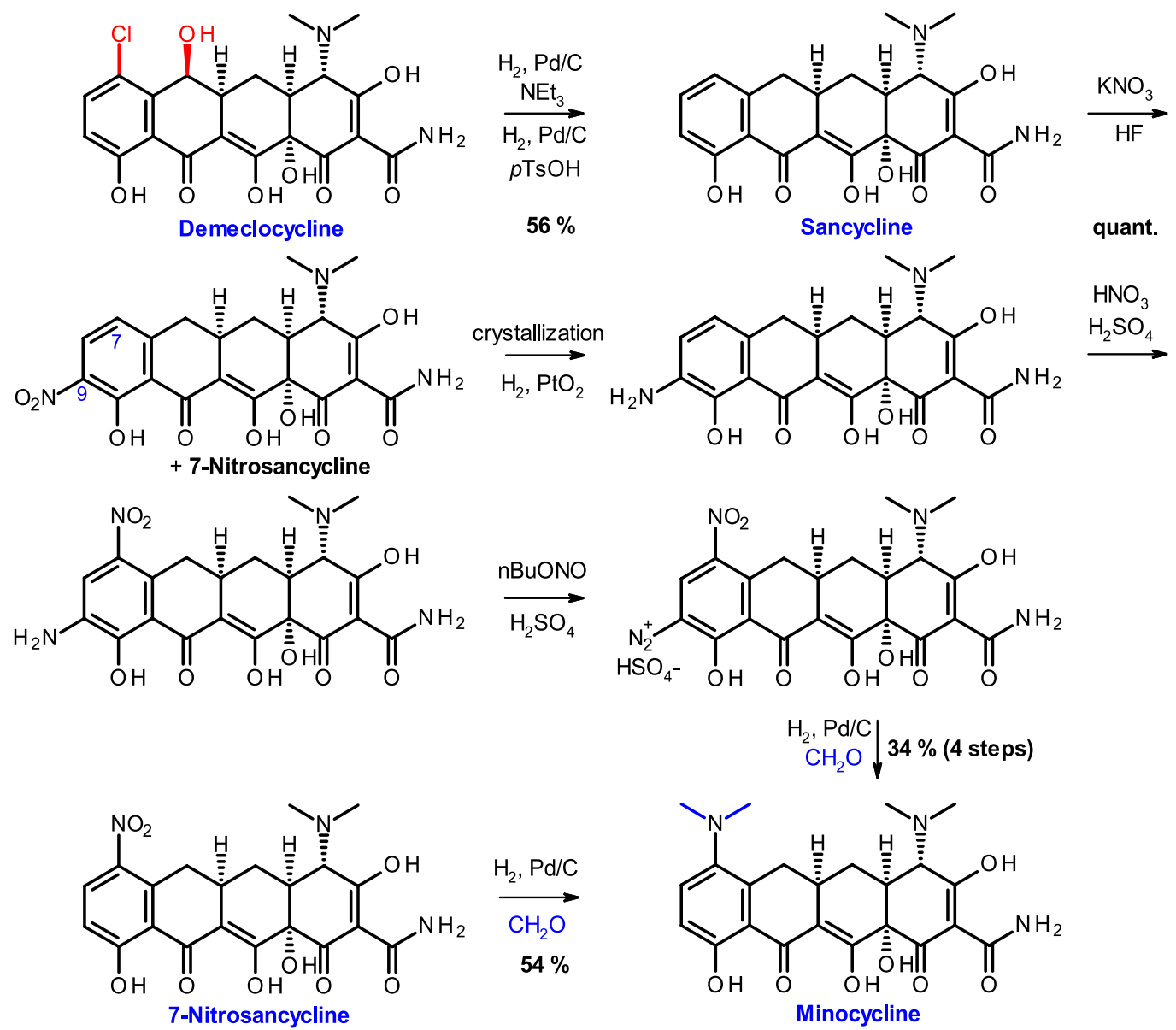

Fig. 46 The synthesis of minocycline branches at the stage of nitrosancycline as a consequence of unselective nitration

easier access to tigecycline [128]. These have meanwhile been adapted and optimized by Chinese companies. Thus, tigecycline is prepared from minocycline simply by nitration, hydrogenation, and treatment with $N$ - $t$-butylglycylchloride (Fig. 47 )[129, 130].

\section{Omadacycline}

In 2002, Mark L. Nelson at Tufts University School of Medicine and Paratek Pharmaceuticals claimed 9-aminomethylminocycline derivatives with improved in vivo activity against Gram-positive pathogens exhibiting tetracycline resistance brought about by efflux (Tet K in Staphylococcus aureus and Tet L in Enterococcus faecalis) and ribosomal protection (Tet M in Staphylococcus aureus, Enterococcus faecalis, and Streptococcus pneumoniae) [131-133].

\section{Info box: Mark L. Nelson}

In 2010, after dissolution of bone samples in hydrogen fluoride, Mark L. Nelson succeeded in "Mass spectroscopic characterization of tetracycline in the skeletal remains of an ancient population from Sudanese Nubia, 350-550 CE” [27, 134].

Omadacycline (9-neopentylaminomethylminocycline) proved to be similarly potent as tigecycline in some tests, but was more active against resistant pathogenic strains compared not only to most tetracyclines but also to vancomycin and ciprofloxacin (Table 2) [135]. In 2018, the antibiotic was approved by the US Food and Drug Administration (FDA) for the treatment of communityacquired pneumonia and acute skin and skin structure infections [136]. 
<smiles></smiles><smiles>CN(C)c1cc([N+](=O)[O-])c(O)c2c1C[C@H]1C[C@H]3[C@H](N(C)C)C(O)=C(C(N)=O)C(=O)[C@@]3(O)C(O)=C1C2=O</smiles><smiles>CN(C)c1cc(N)c(O)c2c1C[C@H]1C[C@]3(C)C(=C(O)[C@]2(O)C1=O)C(=O)C(C(N)=O)=C(O)[C@@H]3N(C)C</smiles><smiles>CN(C)c1cc(NC(=O)CNC(C)(C)C)c(O)c2c1C[C@H]1C[C@H]3[C@H](N(C)C)C(O)=C(C(N)=O)C(=O)[C@]3(O)C(O)=C1C2=O</smiles>

Fig. 47 Tigecycline synthesis, as described in Chinese patents. It is a high value-added partial synthetic tetracycline

\section{Info box: Tetracyclines and bioterrorism}

Engineered resistant germs, i.e., those of Yersinia pestis and Bacillus anthracis (the causative pathogens of anthrax), pose an increasing threat of bioterrorism. The options of defense with established antibiotics are limited. Thus, there is an urgent need for new drugs for prophylaxis and medical treatment. In 2017, Paratek demonstrated the potential of omadacycline and doxycycline in comparison to tetracycline and ciprofloxacin (fluoroquinoline) as reference substances (Table 3). In a postexposure prophylaxis study in mice, omadacycline and doxycycline revealed convincing efficacy as well, which warrants further assessment in combating these serious biothreat organisms [137].
For the preparation of the first multi-kilogram quantities of omadacycline, Paratek reacted minocycline hydrochloride with hydroxymethylphthalimide in triflic acid, which unfortunately not only led to alkylation at position 9 but also to the functionalization of the carboxamide at position 1 and the phenol group at position 10 . Deprotection with excess methylamine in ethanol at room temperature afforded an unstable mixture of mono- and diaminomethyl minocycline along with the waste of $N^{1}, N^{2}$-dimethylphthalamide. In a third and fourth step,

Table 2 Comparison of the minimum inhibitory concentration (MIC, $\mu \mathrm{g} / \mathrm{ml}$ ) of omadacycline with some other tetracyclines, vancomycin, and ciprofloxacin against wild-type and tetracycline-resistant Gram-positive bacteria

\begin{tabular}{|c|c|c|c|c|c|c|c|c|c|}
\hline \multirow[t]{2}{*}{ Compound } & \multicolumn{3}{|c|}{ Staphylococcus aureus } & \multicolumn{3}{|c|}{ Enterococcus faecalis } & \multirow{2}{*}{$\begin{array}{l}\text { Enterococcus faecium } \\
\text { Tet } \mathrm{M}+\mathrm{L}\end{array}$} & \multicolumn{2}{|c|}{$\begin{array}{l}\text { Streptococcus pпеи- } \\
\text { moniae }\end{array}$} \\
\hline & Wild type & Tet $\mathbf{M}$ & Tet $\mathrm{K}$ & Wild type & Tet $\mathbf{M}$ & Tet L & & Wild type & Tet $\mathbf{M}$ \\
\hline Tetracycline & $<0.06$ & 32 & $>64$ & 0.25 & $>64$ & 64 & $>64$ & $<0.06$ & 32 \\
\hline Minocycline & 0.25 & 2 & 0.5 & 0.5 & 16 & 0.5 & 16 & $<0.06$ & 8 \\
\hline Tigecycline & 0.25 & 0.25 & 0.5 & 0.5 & 0.5 & 0.5 & 0.5 & $<0.06$ & $<0.06$ \\
\hline Vancomycin & 0.5 & 0.5 & 0.25 & 1 & 1 & 1 & $>64$ & 0.25 & 0.25 \\
\hline Ciprofloxacin & 0.5 & 16 & 0.5 & 1 & 1 & 1 & 1 & 0.5 & 0.5 \\
\hline Omadacycline & 0.25 & 0.25 & 0.25 & 0.25 & 0.5 & 0.5 & 0.5 & 0.06 & 0.06 \\
\hline
\end{tabular}

Weaknesses of efficacy are highlighted in bold. As a result of the increasing number of vancomycin- and multidrug-resistant strains of Enterococcus faecium, there are few antibiotics available for the treatment of device-related infections (e.g., those due to urinary drainage catheters and ventilators), which makes omadacycline's high activity a coveted property

Table 3 MIC ranges for 30 strains of Yersinia pestis and Bacillus anthracis

\begin{tabular}{lllll}
\hline Strain & $\begin{array}{l}\text { Omadacycline (MIC, } \\
\mu \mathrm{g} / \mathrm{ml})\end{array}$ & $\begin{array}{l}\text { Doxycycline (MIC, } \\
\mu \mathrm{g} / \mathrm{ml})\end{array}$ & $\begin{array}{l}\text { Tetracycline (MIC, } \\
\mu \mathrm{g} / \mathrm{ml})\end{array}$ & $\begin{array}{l}\text { Ciprofoxacin } \\
(\mathrm{MIC}, \mu \mathrm{g} / \\
\mathrm{ml})\end{array}$ \\
\hline Yersinia pestis & $0.12-2$ & $0.06-2$ & $0.25-2$ & $0.004-0.06$ \\
Bacillus anthracis & $<0.03-0.06$ & $0.03-0.06$ & $<0.03-1$ & $0.03-0.25$ \\
\hline
\end{tabular}


reductive amination with pivaldehyde concomitant with deaminomethylation of the amide and followed by reversed-phase chromatographic purification and precipitation yielded omadacycline in pure form. However, the amorphous solid proved to be unstable on storage as well (Fig. 48) [138].

For the manufacturing of the commercial product, an enhanced synthetic route was needed that addressed the following shortcomings:

1. Selectivity of hydroxymethylphthalimide alkylation

2. Instability of diaminomethyl minocycline

3. Instability of amorphous omadacycline

Paratek conquered these issues by installing the entire side chain in one step by an electronically tuned Tscherniac-Einhorn reaction. The alkylation reagent is conveniently obtained in two steps from neopentylamine, paraformaldehyde, and chloroacetic anhydride. Removal of the chloroacetyl and the hydroxymethyl groups is achieved in aqueous $\mathrm{HCl}$, followed by readjustment of the stereochemical integrity at position 4 by treatment with a mixture of calcium chloride in $n$-butanol, water, and ethanolamine or sodium hydroxide at elevated temperature. After chromatographic purification, the crystalline tosylate salt is formed, which provides omadacycline adequate long-term stability as the final active pharmaceutical ingredient (API) (Fig. 49) [139].

\section{Sarecycline}

The close collaboration between Tufts University and Paratek at the beginning of this century brought about a second tetracycline, which was branded sarecycline. Initially it was developed together with Allergan. In 2018, Spain's Almirall acquired the dermatological portfolio from Allergan and gained FDA approval for sarecycline for the treatment of moderate to severe acne vulgaris in the same year [141-143].

The starting material for the manufacturing of sarecycline is sancycline, which is iodinated by the use of $N$-iodosuccinimide in trifluoroacetic acid $[144,145]$. Palladium-catalyzed carbonylation in the presence of tributyltin hydride leads to 7-formyl sancycline, from which sarecycline is obtained by reductive amination with sodium cyanoboranate and $\mathrm{N}, \mathrm{O}$-dimethylhydroxylamine (Fig. 50) [146, 147].

\section{Eravacycline}

Eravacycline is a third-generation tetracycline, which received FDA approval in 2018 for the treatment of complicated intra-abdominal infections in adults aged 18 and older. It was developed by Tetraphase and displays broad activity against Gram-positive and Gramnegative bacteria, including multidrug-resistant strains,<smiles>CN(C)c1ccc(O)c2c1C[C@H]1C[C@]3(C)C(=C(O)[C@]2(O)C1=O)C(C(N)=O)=C(O)[C@@H]3N(C)C</smiles>

$\mathrm{xHCl}$ Minocycline $\mathrm{HCl}$<smiles>[R]CN[14CH2]N[R]</smiles><smiles>O=C1c2ccccc2C(=O)N1CO</smiles><smiles>[C-]#[SbH2]</smiles><smiles>CC(C)(C)C=O</smiles>
$\mathrm{NEt}_{3}, \mathrm{MeOH}$ chromatography

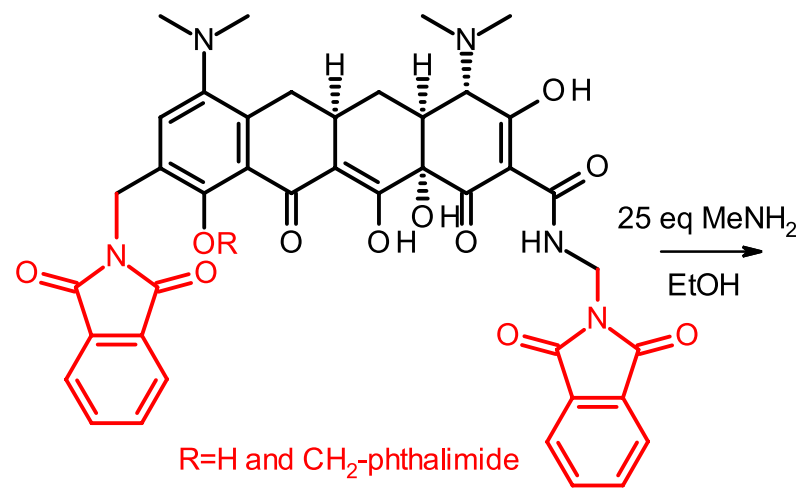<smiles>CNCc1cc(N(C)C)c2c(c1O)C(=O)C1=C(O)[C@]3(O)C(=O)C(C(N)=O)=C(O)[C@@H](N(C)C)[C@@]3(C)C[C@@H]1C2</smiles>

$15-18 \%$ (3 steps)

Fig. 48 The first multi-kilogram synthesis of omadacycline 
<smiles>CC(C)(C)CN</smiles>

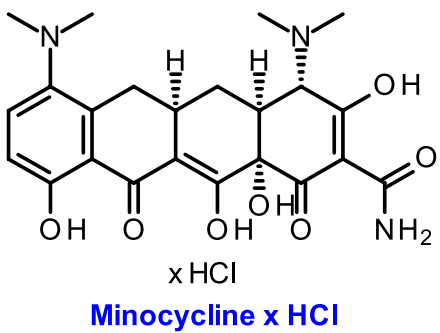<smiles>CC(C)(C)CN(COC(=O)CCl)C(=O)CCl</smiles>

$83 \%$<smiles>CN(C)c1cc(CN(CC(C)(C)C)C(=O)Cl)c(O)c2c1C[C@H]1C[C@H]3[C@H](N(C)C)C(O)=C(C(=O)NCO)C(=O)[C@@]3(O)C(O)=C1C2=O</smiles><smiles>CN(C)c1cc(CNCC(C)(C)C)c(O)c2c1C[C@H]1C[C@H]3[C@H](N(C)C)C(O)=C(C(N)=O)C(=O)[C@]3(O)C(O)=C1C2=O</smiles>

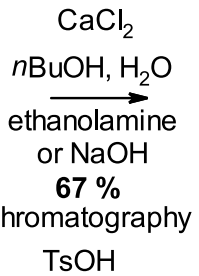

Fig. 49 Key step of Paratek's improved synthesis is a TscherniacEinhorn reaction, which was published first by Joseph Tscherniac in 1901. In 1905, Alfred Einhorn (1856-1917) described a more general

i.e., methicillin-resistant Staphylococcus aureus and carbapenem-resistant Entereobacteriacae [149].

Once developed, Tetraphase adopted Andrew Myers' synthetic approach of azatetracyclines by Michael-Dieckmann condensation [150]. In collaboration with him, they synthesized and tested a variety of 8-azatetracyclines with different substituents at position 7 in an in vitro assay with Staphylococcus aureus, Streptococcus pneumoniae, and Klebsiella pneumoniae. The 7-fluoro analogue was found to be most potent; however, the corresponding 9-glycylamido-8-azatetracyclines failed to exhibit activity in whole-cell assays.

Similarly, Tetraphase also investigated a series of pentacyclines, but without much success.

Finally, Tetraphase went back to modifications of the tigecycline substitution pattern and found superior activity in those cases in which the 7-dimethylamino group condensation method of $\mathrm{N}$-hydroxymethyl chloroacetamide with aromatic compounds [140]

was replaced by fluorine. Although not completely new, 7-fluorotetracyclines were synthesized as early as in 1962 [151], Tetraphase designated this group of compounds as "fluorocyclines" $[152,153]$ and selected and developed a particular analogue to market launch, which eventually was named eravacycline [154]. It proved to be active not only against strains carrying the three main tetracyclinespecific efflux pumps but also against ribosomal protection mechanisms and enzymes that target tetracyclines. Moreover, it retains activity also against pathogens resistant to multiple antibiotic classes, among also those expressing $\beta$-lactamases.

To provide an adequate amount of material for upcoming clinical studies Tetraphase chose Myers' initial route for synthesis improvement and upscaling. This was a remarkable decision by which eravacycline became the 
<smiles>CN(C)[C@H]1C(O)=C(C(N)=O)C(=O)[C@]2(O)C(O)=C3C(=O)c4c(O)cccc4C[C@H]3C[C@]12C</smiles>

$N$-lodosuccinimide TFA

$75 \%$<smiles>C[C@@H]1[C@@H]2Cc3c(I)ccc(O)c3C(=O)C2=C(O)[C@@]2(O)C(=O)C(C(N)=O)=C(O)[C@H](N(C)C)[C@]12C</smiles>
$\mathrm{CO}$ $\mathrm{Pd}\left(\mathrm{PPh}_{3}\right)_{4}$ $\overrightarrow{n \mathrm{Bu}_{3} \mathrm{SnH}}$ DMF

Sancycline<smiles>CN(C)[C@H]1C(O)=C(C(N)=O)C(=O)[C@]2(O)C(O)=C3C(=O)c4c(O)ccc(C=O)c4C[C@H]3C[C@]12C</smiles>

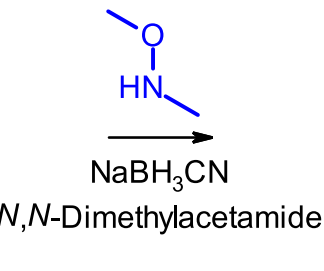

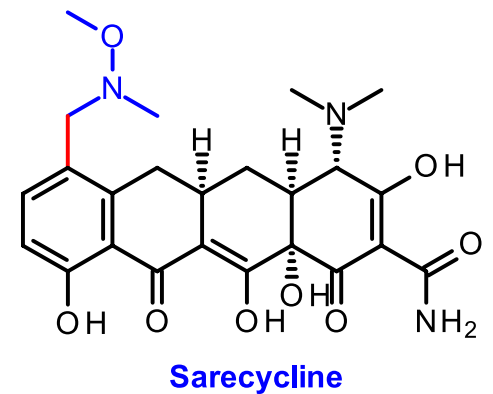

Fig. 50 Paratek's synthesis of sarecycline. The functionalization of sancycline at position 7 is achieved by iodination and palladium-catalyzed formylation with carbon monoxide and tri- $n$-butyltin hydride,

first fully synthetic tetracycline, manufactured in multikilogram scale $[150,155]$.

The synthesis commences with the bromination of dimethyl maleate. Subsequent reaction with hydroxy urea forms an isoxazole. Protection and DIBAlH reduction furnishes an isoxazole carbaldehyde. Applying the Ellman auxiliary in a diastereoselective Grignard reaction leads to a highly enantioenriched allyl amine, which after reductive methylation and salt formation delivers the a method developed by John Kenneth Stille (1930-1989) at Colorado State University in the 1980s [148]

final product of the first part of Tetraphase's synthesis of eravacycline (Fig. 51) [156].

After liberation of the isoxazole from its tartrate salt, it is condensed with methoxy furfural applying 2,2,6,6-tetramethylpiperidine magnesium chloride (TMPMgCl) as base. After intramolecular diastereoselective Diels-Alder reaction sulfur trioxide pyridine is added, which leads to oxidation of the alcohol by Parikh-Doehring's method. Tandem cleavage of the oxabicycle and the vinyl ether by boron trichloride

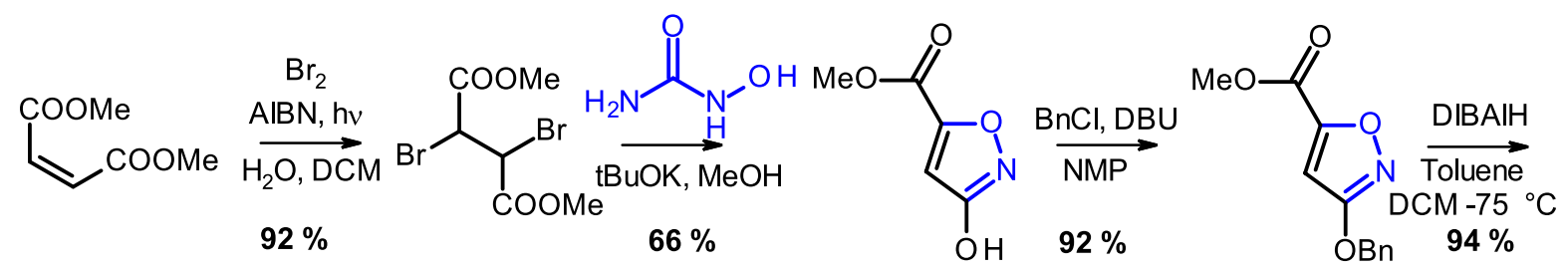<smiles>CC(C)(C)[S@@](=O)N=Cc1cc(OCc2ccccc2)no1</smiles>

$85 \%$

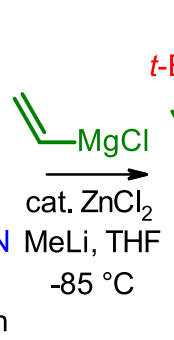

-Bun..s'

$98.6 \%$ de

Fig. 51 First part of Tetraphase's total synthesis of eravacycline 
followed by TBS protection of the tertiary alcohol and purification by charcoal/silica treatment and crystallization affords the AB ring building block (Fig. 52) [157].

The tetracycline scaffold of eravacycline is established by Myers' Michael-Dieckmann-type condensation. After global deprotection, first by treatment with hydrogen fluoride and then by hydrogenolysis, the amino group at position 9 is acylated. Finally, the total synthesis of eravacycline $2 \mathrm{HCl}$ is accomplished by salt formation. The longest linear sequence of the total synthesis comprises 17 steps and delivers the API in $16.2 \%$ overall yield (Fig. 53) [155].<smiles>C=C[C@@H](c1cc(OCc2ccccc2)no1)N(C)C</smiles><smiles>COc1ccoc1C=O</smiles><smiles>C=C[C@@H](c1onc(OCc2ccccc2)c1[C@H](O)c1occc1OC)N(C)C</smiles>

DMSO, DIPEA

$\underset{\text { EtOAC }}{\stackrel{\mathrm{SO}_{3} \text {-py }}{\longrightarrow}}$ recrystallization

$74 \%$ (2 steps)<smiles>COC1=C[C@H]2C[C@H]1[C@@H](N(C)C)c1onc(OCc3ccccc3)c1C2=O</smiles><smiles>[13CH3][13CH3]</smiles>

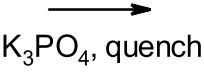

$90 \%$<smiles>CN(C)[C@H]1c2onc(OCc3ccccc3)c2C(=O)[C@]2(O)C(=O)C=CC[C@@H]1[C@@H](N(C)C)c1onc(OCc3ccccc3)c1C2=O</smiles>

Fig. 52 Second part of Tetraphase's total synthesis of eravacycline

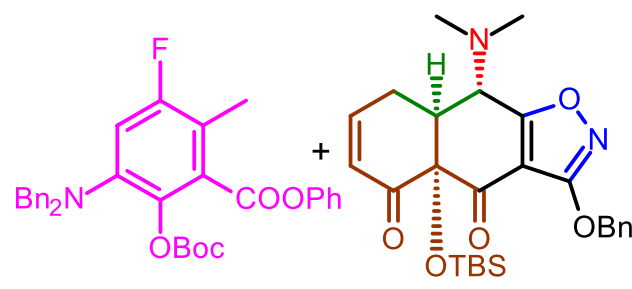

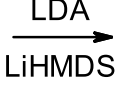

$94 \%$<smiles>CC(C)Cc1noc2c1C(=O)[C@@]1(C)C(O)=C3C(=O)c4c(c(F)cc(NCc5ccccc5)c4OCc4ccccc4)C[C@H]3C[C@@H]1[C@H]2N(C)C</smiles>

aq. HF

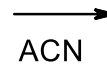

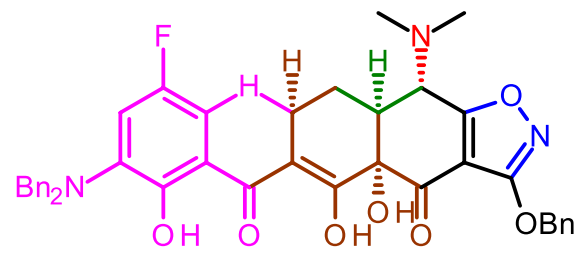<smiles>CN(C)[C@H]1C(O)=C(C(N)=O)C(=O)[C@@]2(O)C(O)=C3C(=O)c4c(O)c(N)cc(F)c4C[C@H]3C[C@]12C(C)(C)O</smiles>

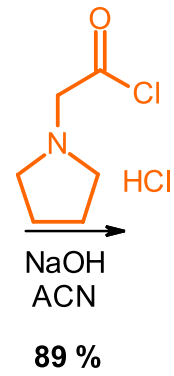<smiles>CCOC(C)(C)CC</smiles>

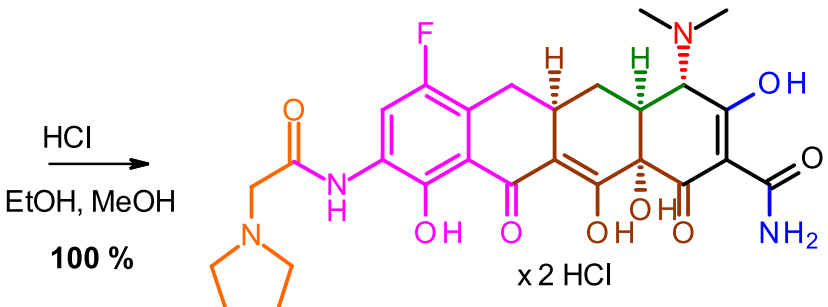

Eravacycline

Eravacycline $\times 2 \mathrm{HCl}$

Fig. 53 Third part of Tetraphase's total synthesis of eravacycline 
In general, as part of the development work of a new API, pharmaceutical companies invest some effort in investigating alternative synthetic routes and process improvements. In the case at hand, for the preparation of $11-{ }^{14} \mathrm{C}$-labeled material, Tetraphase aimed at a concise, highly convergent synthesis, constructing the scaffold of eravastatine from a fully garnished $\mathrm{D}$ ring and the $\mathrm{AB}$ fragment of the main route by Michael-Dieckmann reaction [158].

Starting from commercially available 4-fluoro3 -methylphenol the synthesis commences with a onepot 2,6-dibromination and regioselective Zincke nitration (named after Theodor Zincke (1843-1928), a German chemist at the Philipps University of Marburg) [159, 160]. After protection of the phenol as benzyl ether, the nitro group is reduced employing sodium dithionite and then subjected to reductive amination with $p$-methoxy benzaldehyde and sodium triacetoxyboranate, in order to avoid double acylation with pyrrolidin-1-ylacetyl chloride. Initially, the carboxylic ester was obtained by Grignard reaction with carbon dioxide and DMAP-catalyzed esterification with phenol. Especially the last steps, however, suffered from complicated, tedious operations and poor yields (Fig. 54).

Therefore, the chemists at Tetraphase turned to palladium-catalyzed carboxylation with phenyl formate. After some experimentation they found a protocol providing the $\mathrm{D}$ ring building block in $66 \%$ yield.

The Michael-Dieckmann condensation was performed as in the manufacturing process, using lithium

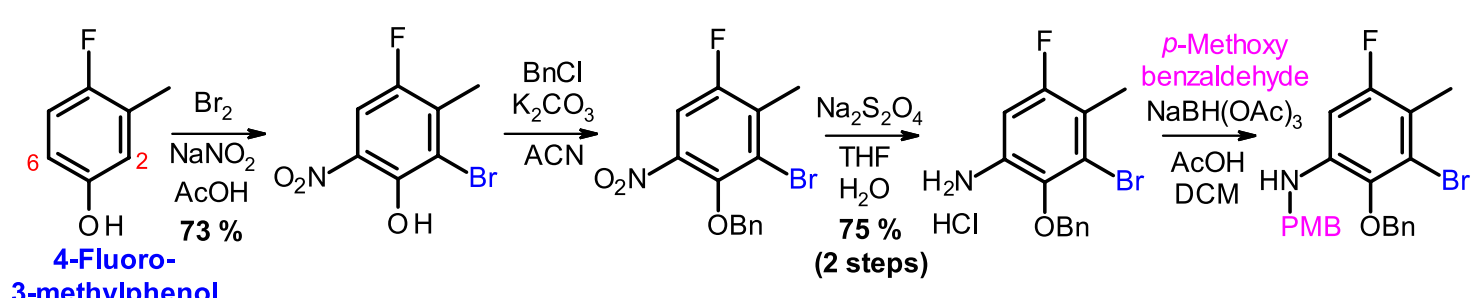
3-methylphenol<smiles>O=C(Cl)CN1CC2CCCCC21</smiles>

$66 \%$ (2 steps)<smiles>CCCCCN(C(=O)CN1CCCC1)c1cc(F)c(C)c(Br)c1OC(C)(C)C</smiles><smiles>CC(C)(C)[Ge]Cl</smiles><smiles>CCCCCCCCOc1c(N(CCCCC)C(=O)CN2CCCC2)cc(F)c(C)c1C(=O)O</smiles>

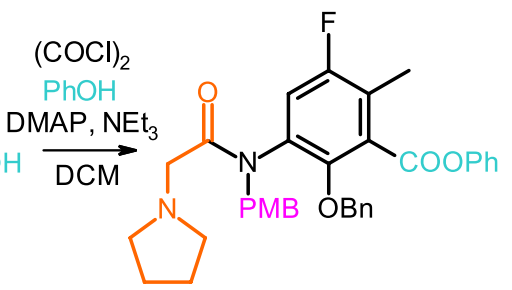

Fig. 54 Synthesis of the D ring building block of Tetraphase's convergent synthesis of eravacycline<smiles>CCCCN(C(=O)CN1CCCC1)c1cc(F)c(C)c(Br)c1OCc1ccccc1</smiles>

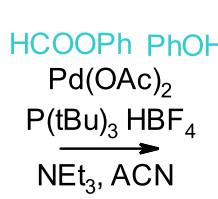

$66 \%$

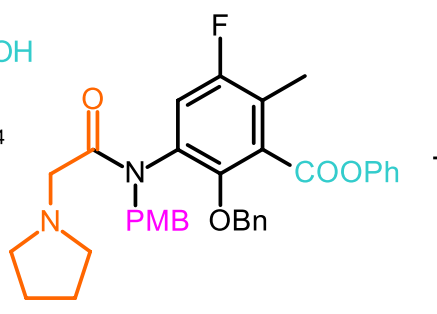<smiles>CC(C)Cc1noc2c1C(=O)[C@@]1(C(=O)O)C(=O)C=CC[C@]1(C)[C@H]2N(C)C</smiles>
LDA $\underset{\mathrm{THF}}{\stackrel{\mathrm{TEA} \mathrm{HCl}}{\longrightarrow}}$<smiles>CN(C)[C@H]1c2onc(OCc3ccccc3)c2C(=O)[C@@]2(C)C(=O)C3=C(Cc4c(F)cc(N([15CH2])C(=O)CN5CCCC5)c(Br)c4C3=O)C[C@]12O</smiles>

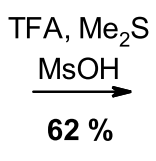<smiles>CCNC(=O)CN1CCCC1</smiles>

$70 \%$

Fig. 55 Final steps of Tetraphase's convergent synthesis of eravacycline 
diisopropylamide as base [155]. However, the initial strategy of deprotection by acidic removal of the TBS, both benzyl and the PMB groups, followed by reductive opening of isoxazole ring failed. All conditions tried suffered from incomplete deprotection and the formation of side products. The problem was finally solved by performing global deprotection using a mixture of trifluoroacetic acid, methanesulfonic acid, and dimethyl sulfide. Employing dimethyl sulfide brought about a twofold advantage: it prevented the formation of cation-derived side products and simultaneously acted as a reducing agent, facilitating the cleavage of the isoxazole (Fig. 55).

In another approach to eravacycline, Tetraphase also investigated a more traditional route, starting from sancycline [161]. At the onset of the synthesis, 9-aminosancycline is synthesized by blocking position 7 by NBS-induced bromination, nitration, and simultaneously debromination and reduction of the nitro group. After a second nitration at position 7 , by reaction with 2-pyrrolidin-1-ylacetyl chloride, the corresponding amide is obtained. Hydrogenation provides a 7 -amino eravacycline precursor, which is subjected to a Balz-Schiemann reaction (named after the German chemists Günther Balz and Günther Schiemann [162]), which comprises diazotization of the amino group and displacement of the diazonium salt formed by fluoride, facilitated by irradiation with UV light (254 nm) (Fig. 56).<smiles>CN(C)[C@H]1C(O)=C(C(N)=O)C(=O)[C@]2(O)C(O)=C3C(=O)c4c(O)cccc4C[C@H]3C[C@H]12</smiles><smiles>CN(C)[C@H]1C(O)=C(C(N)=O)C(=O)[C@]2(O)C(O)=C3C(=O)c4c(O)ccc(Br)c4C[C@H]3C[C@H]12</smiles>

Sancycline<smiles>CN(C)[C@H]1C(O)=C(C(N)=O)C(=O)[C@]2(O)C(O)=C3C(=O)c4c(O)c([N+](=O)[O-])cc(Br)c4C[C@H]3C[C@H]12</smiles><smiles>CCCP</smiles><smiles>CN(C)[C@H]1C(O)=C(C(N)=O)C(=O)[C@]2(O)C(O)=C3C(=O)c4c(ccc(N)c4O)C[C@H]3C[C@]12C</smiles><smiles>N#CC1C=CCN1CC(=O)Cl</smiles><smiles>CN(C)[C@H]1C(O)=C(C(N)=O)C(=O)[C@]2(O)C(O)=C3C(=O)c4c(O)c(N)cc([N+](=O)[O-])c4C[C@H]3C[C@H]12</smiles>

ACN<smiles>CCC(=O)Nc1cc([N+](=O)[O-])c2c(c1O)C(=O)C1=C(O)[C@]3(O)C(=O)C(C(N)=O)=C(O)[C@@H](N(C)C)[C@]3(C)C[C@H]1C2</smiles><smiles>CN(C)[C@H]1C(O)=C(C(N)=O)C(=O)[C@]2(O)C(O)=C3C(=O)c4c(O)c(NC(=O)CN5CCCC5)cc(N)c4C[C@H]3C[C@H]12</smiles>

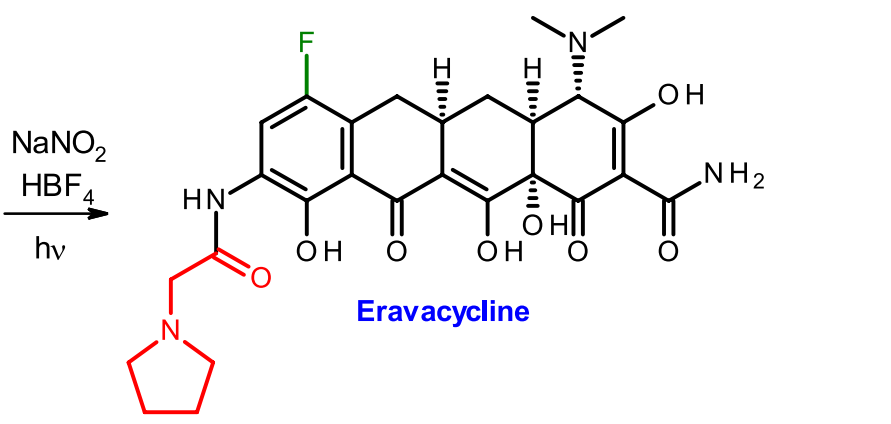

Fig. 56 Partial synthesis of eravacycline from sancycline 

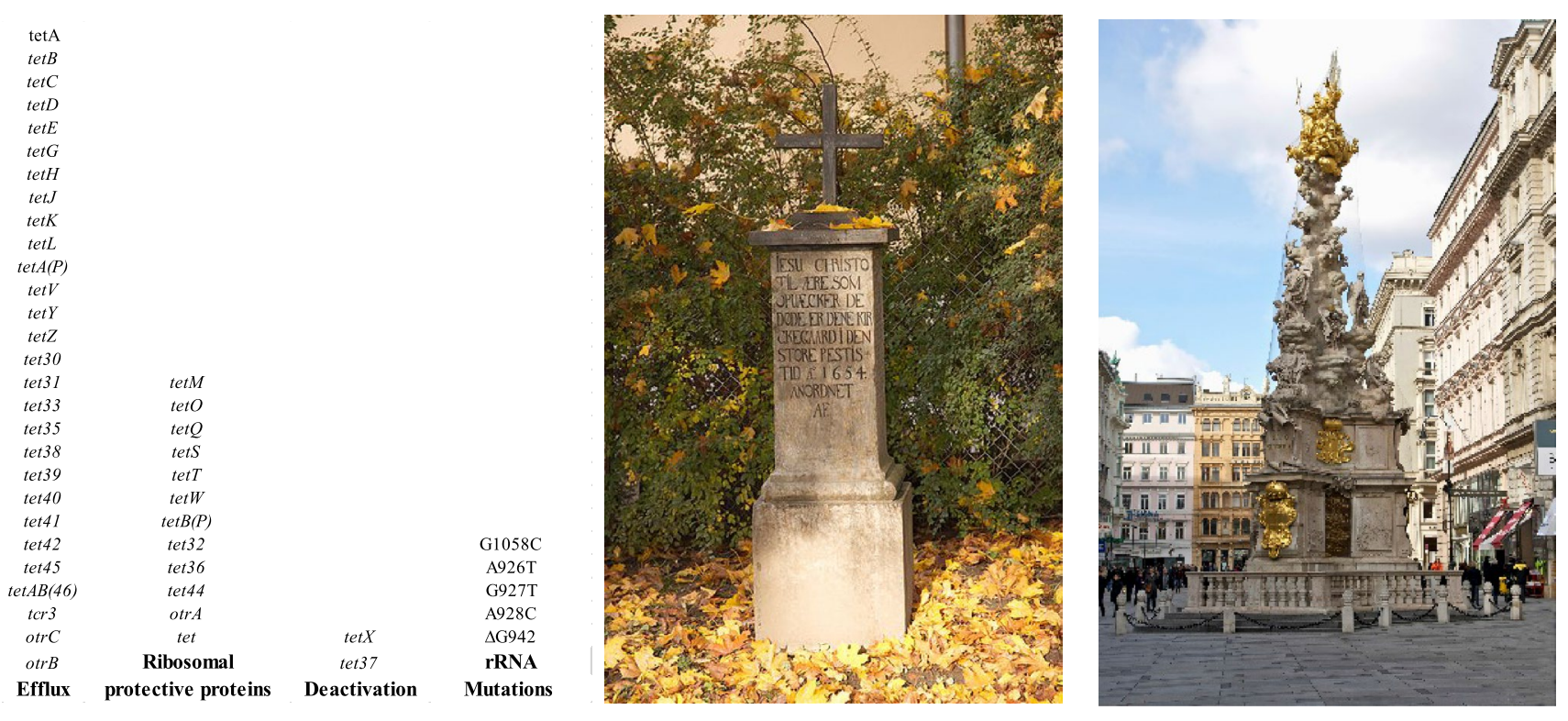

Fig. 57 The tetracycline resistance determinants [56] pile up similar to the plague monument at Oslo of 1654 and the famous baroque Vienna plague memorial of 1679 (@ Paalso, Thomas Ledl)

Since sancycline is readily obtained from demeclocycline by hydrogenation, this route seems to be highly attractive for large-scale manufacturing, providing eravacycline in just seven steps, regardless of all achievements of contemporary organic chemistry and contributions to total synthesis.

\section{Concluding remarks}

The tetracyclines are still among the most valuable broadspectrum antibiotics despite several "hospital bugs", especially Pseudomonas aeruginosa or Proteus and Enterobacter strains, having grown resistance against them. They are still used in therapy (acne, plague, Rocky mountain spotted fever, typhoid fever) and in prophylaxis against severe illnesses (anthrax, malaria), in which they play an important role. Doxycycline is therefore, and justifiably so, on the list of essential medicines of the World Health Organization (WHO Model List of Essential Medicines).

Nonetheless, the long columns in the table of tetracycline resistance genes should also chasten us. They manifest scientifically, which are also made evident by the historic relics of the catastrophic plague epidemics across all of Europe. The plague monuments are not only remembrance of the appalling suffering of humanity in the last centuries but also mementos imploring us to be more responsible in using our armory of modern methods and medications to control epidemics (Fig. 57).
Funding Open Access funding enabled and organized by Projekt DEAL.

Open Access This article is licensed under a Creative Commons Attribution 4.0 International License, which permits use, sharing, adaptation, distribution and reproduction in any medium or format, as long as you give appropriate credit to the original author(s) and the source, provide a link to the Creative Commons licence, and indicate if changes were made. The images or other third party material in this article are included in the article's Creative Commons licence, unless indicated otherwise in a credit line to the material. If material is not included in the article's Creative Commons licence and your intended use is not permitted by statutory regulation or exceeds the permitted use, you will need to obtain permission directly from the copyright holder. To view a copy of this licence, visit http://creativecommons.org/licenses/by/4.0/.

\section{References}

1. http://en.wikipedia.org/wiki/1994_plague_epidemic_in_Surat. Accessed 26 Apr 2020

2. Terzani T (1994) Der Spiegel 40:176-180

3. http://en.wikipedia.org/wiki/List_of_historical_plagues. Accessed 26 Apr 2020

4. Boire NA, Riedel VAA, Parrish NM, Riedel S (2013). J Ancient Dis Prevent Remedies. https://doi.org/10.4172/2329-8731.10001 14

5. http://en.wikipedia.org/wiki/Plague_(disease). Accessed 26 Apr 2020

6. Wade N (2010) The New York Times, https://www.nytimes.com/ 2010/11/01/health/01 plague.html. Accessed 26 Apr 2020

7. Deng W, Burland V, Plunkett G III, Boutin A, Mayhew GF, Liss P, Perna NT, Rose DJ, Mau B, Zhou S, Schwartz DC, Fetherston JD, Lindler LE, Brubaker RR, Plano GV, Straley SC, Nilles ML, Matson JS, Blattner FR, Perry RD (2002) J Bacteriol 184:4601-4611 
8. Parkhill J, Wren BW, Thomson NR, Titball RW, Holden MTG, Prentice MB, Sebaihia M, James KD, Churcher C, Mungall KL, Baker S, Basham D, Bentley SD, Brooks K, Cerdeño-Tárraga AM, Chillingworth T, Cronin A, Davies RM, Davis P, Dougan G, Feltwell T, Hamlin N, Holroyd S, Jagels K, Karlyshev AV, Leather S, Moule S, Oyston PCF, Quail M, Rutherford K, Simmonds M, Skelton J, Stevens K, Whitehead S, Barrell BG (2001) Nature 413:523-527

9. Chain PSG, Hu P, Malfatti SA, Radnedge L, Larimer F, Vergez LM, Worsham P, Chu MC, Andersen GL (2006) J Bacteriol 188:4453-4463

10. Wagner DM, Klunk J, Harbeck M, Devault A, Waglechner N, Sahl JW, Enk J, Birdsell DN, Kuch M, Lumibao C, Poinar D, Pearson T, Fourment M, Golding B, Riehm JM, Earn DJD, DeWitte S, Rouillard JM, Grupe G, Wiechmann I, Bliska JB, Keim PS, Scholz HC, Holmes EC, Poinar H (2014) Lancet Infect Dis 14:319-326

11. Haensch S, Bianucci R, Signoli M, Rajerison M, Schultz M, Kacki M, Vermunt M, Weston DA, Hurst D, Achtman M, Carniel E, Bramanti B (2010) PLoS Pathog 6:e1001134. https://doi.org/ 10.1371/journal.ppat.1001134

12. Keller M, Spyrou MA, Scheib CL, Neumann G, Kröpelin A, Haas-Gebhard B, Päffgen B, Haberstroh J, Ribera I, Lacomba A, Raynaud C, Cessford C, Durand R, Stadlerl P, Nägele K, Bates JS, Trautmann B, Inskip SA, Peters J, Robb JE, Kivisild T, Castex D, McCormick M, Bos KI, Harbeck M, Herbig A, Krause J (2019) Proc Natl Acad Sci USA 116:12363-12372

13. http://en.wikipedia.org/wiki/Third_plague_pandemic. Accessed 26 Apr 2020

14. Doll JM, Zeitz PS, Ettestad P, Bucholtz AL, Davis T, Gage K (1994) Am J Trop Med Hyg 51:109-114

15. https://www.theguardian.com/books/booksblog/2014/aug/01/ plague-fiction-writers-infectious-disease. Accessed 1 May 2020

16. https://de.wikipedia.org/wiki/Pest. Accessed 1 May 2020

17. Urich SK, Chalcraft L, Schriefer ME, Yockey BM, Peterson JE (2011) Antimicrobial Agents Chemotherapy 2011:555-558

18. Ditchburn JL, Hodgkins (2019) Biosafety Health 1:65-70

19. Barrett R, Armelagos G (2013) An unnatural history of emerging infections. Oxford University Press, Oxford, p 95

20. Armelagos GJ, Ewing GH, Greene DL (1968) Anthropol Q 41:122-131

21. https://www.beersyndicate.com/blog/tag/debra-martin/. Accessed 26 Apr 2020

22. Armelagos GJ, Kolbacher K, Collins K, Cook J, Krafeld-Daugherty M (2001) Tetracycline consumption in prehistory. In: Nelson M, Hillen W, Greenwald RA (eds) Tetracyclines in biology, chemistry and medicine. Birkhäuser, Berlin, p 219

23. Bassett EJ, Keith MS, Armelagos GJ, Martin DL (1980) Science 209:1532-1534

24. Cook M, Molto E, Anderson C (1989) Am J Phys Anthropol 80:137-143

25. Hummert JR, van Gerven DP (1982) Hum Biol 54:355-371

26. Grauer A, Armelagos GJ (1998) Skeletal biology of hesban: a biocultural interpretation, in the necropolis of hesban, a typology of tombs, Hesban 10. Andrews University Press, Berrin Springs, p 107

27. Nelson ML, Dinardo A, Hochberg J, Armelagos GJ (2010) Am J Phys Anthropol 143:151-154

28. https://en.wikipedia.org/wiki/Unit 731. Accessed 26 Apr 2020

29. Walker JC (1982) Ann Rev Phytopathol 20:33-39

30. https://en.wikipedia.org/wiki/Sanborn_Field\#cite_ref-Aureo mycin 4-0. Accessed 26 Apr 2020

31. Duggar BM (1948) Ann NY Acad Sci 51:177-181

32. Duggar BM (1949) US2482055

33. Winfried Hinrichs, personal communication (2020)

34. Nelson ML, Levy SB (2011) Ann NY Acad Sci 2011:17-32
35. Finlay AC, Hobby GL, Pan SY, Regna PP, Routien JB, Seeley DB, Shull GM, Sobin BA, Solomons IA, Vinson JW, Kane JH (1950) Science 111:85-85

36. Sobin BA, Finlay AC, Kane JH (1949) US2516080

37. Stephens CR, Conover LH, Hochstein FA, Regna PP, Pilgrim FJ, Brunings KJ, Woodward RB (1952) J Am Chem Soc 74:4976-4977

38. Donohue J, Dunitz JD, Trueblood KN, Webster MS (1963) J Am Chem Soc 85:851-856

39. von Wittenau SM, Blackwood RK, Conover LH, Glauert RH, Woodward RB (1965) J Am Chem Soc 87:134-135

40. Blout E, Woodward RB (2001) Nat Acad Sci Biograph Memoirs 80:367-387

41. Conover LH (1955) US 2699054

42. http://en.wikipedia.org/wiki/Tetracycline. Accessed 26 Apr 2020

43. Braithwaite $\mathbf{J}$ (1984) Corporate Crime in the pharmaceutical industry. Routledge \& Kegan Paul, London, Boston, Melbourne and Henley, pp 12-13. http://en.wikipedia.org/wiki/American Cyanamid. Accessed 26 Apr 2020

44. Aleksandrov A, Simonson T (2006) J Comput Chem 27:1517-1533

45. Volkers G, Petruschka L, Hinrichs W (2011) J Med Chem 54:5108-5115

46. Orth P, Saenger W, Hinrichs W (1999) Biochemistry 38:191-198

47. Heffron SE, Mui S, Aorora A, Abel K, Bergmann E, Jurnak F (2006) Acta Crystallogr D Biol Crystallogr 62:1392-1400

48. Brodersen DE, Clemons WM Jr, Carter AP, Morgan-Warren RJ, Wimberly BT, Ramakrishnan V (2000) Cell 103:1143-1154

49. Pioletti M, Schlunzen F, Harms J, Zarivach R, Gluhmann M, Avila H, Bashan A, Bartels H, Auerbach T, Jacobi C, Hartsch T, Yonath A, Franceschi F (2001) EMBO J 20:1829-1839

50. Palm GJ, Lederer T, Orth P, Saenger W, Takahashi M, Hillen W, Hinrichs W (2008) J Biol Inorg Chem 13:1097-1110

51. Jenner L, Starosta AL, Terry DS, Mikolajka A, Filonava L, Yusupov M, Blanchard SC, Wilson DN, Yusupova G (2013) Proc Natl Acad Sci USA 110:3812-3816

52. Zakeri B, Wright GD (2008) Biochem Cell Biol 86:124-136

53. Connell SR, Tracz DM, Nierhaus KH, Taylor DE (2003) Antimicrob Agent Chemther 47:3675-3681

54. https://en.wikipedia.org/wiki/16S_ribosomal_RNA. Accessed 1 May 2020

55. Tsiboli P, Herfurth E, Choli T (1994) Eur J Biochem 226:169-177

56. Nguyen F, Starosta AL, Arenz S, Sohmen D, Dönhöfer A, Wilson DN (2014) Biol Chem 395:559-575

57. Budkevich TV, Elskaya AV, Nierhaus KH (2008) Nucleic Acids Res 36:4736-4744

58. Sapadin AN, Fleischmajer R (2006) J Am Acad Dermatol 54:258-265

59. Perret LJ, Tait CP (2014) Austr J Dermatol 55:111-118

60. Wilcox JR, Covington DS, Paez N (2012) Wounds 24:339-349

61. O'Dell JR, Blakely KW, Mallek JA, Eckhoff PJ, Leff RD, Wees SJ, Sems KM, Fernandez AM, Palmer WR, Klassen LW, Paulsen GA, Haire CE, Moore GF (2001) Arthritis Rheum 44:2235-2241

62. Tilley BC, Alarcon GS, Heyse SP, Trentham DE, Neuner R, Kaplan DA, Clegg DO, Leisen JC, Buckley L, Cooper SM, Duncan H, Pillemer SR, Tuttleman M, Fowler SE (1995) Ann Intern Med 122:81-89

63. McEvoy T (2016) Hosp Pharm 51:535-538

64. Pruzanski W, Greenwald RA, Street IP, Laliberte F, Stefanski E, Vadas P (1992) Biochem Pharmacol 44:1165-1170

65. Dalm D, Palm GJ, Aleksandrov A, Simonson T, Hinrichs W (2010) J Mol Biol 398:83-96

66. Valentin S, Morales A, Sánchez JL, Rivera A (2009) Clin Cosmet Investig Dermatol 2:129-140 
67. National Center for Biotechnology Information (2020) PubChem compound summary for CID 54694363, doxycycline calcium. https://pubchem.ncbi.nlm.nih.gov/compound/Doxycycline-calci um. Accessed 27 Dec 2020

68. Stokstad ELR, Jukes TH, Pierce J, Page AC Jr, Franklin AL (1949) J Biol Chem 180:647-654

69. Levy SB, McMurry L (1974) Biochem Biophys Res Comm 56:1060-1068

70. Saenger W, Orth P, Kisker C, Hillen W, Hinrichs W (2000) Angew Chem Int Ed 39:2042-2052

71. Van Bambeke F, Pagès JM, Lee VJ (2010) Front Anti-Infective Drug Discov 1:138-175

72. Spengler G, Kincses A, Gajdács M, Amaral L (2017). Molecules. https://doi.org/10.3390/molecules22030468

73. Volkers G, Palm GJ, Weiss MS, Wright GD, Hinrichs W (2011) FEBS Lett 585:1061-1066

74. Volkers G, Damas JM, Palm GJ, Panjikar S, Soares CM, Hinrichs W (2013) Acta Crystallogr Sect D Biol Crystallogr 69:1758-1767

75. Petkovic S, Hinrichs W (2017) Nat Chem Biol 13:694-695

76. Park J, Gasparrini AJ, Reck MR, Symister CT, Elliott JL, Vogel JP, Wencewicz TA, Dantas G, Tolia NH (2017) Nat Chem Biol 13:730-736

77. Bauer G, Berens C, Projan S, Hillen W (2004) J Antimicrob Chemother 53:592-599

78. Chopra I, Roberts M (2001) Microbiol Mol Biol Rev 65:232-260

79. Sum PE, Petersen P (1999) Bioorg Med Chem Lett 9:1459-1462

80. Fuoco D (2012) Antibiotics 1:1-13

81. Saleha T, Syed Faheem AR, Ummar A (2018). Biomed J Sci Tech Res. https://doi.org/10.26717/-BJSTR.2018.07.001475

82. Tariq S, Faheem S, Rizvi A, Anwar U (2018) Biomed J Sci Tech Res 7:5787-5796

83. Excellent survey. http://www.scripps.edu/baran/images/grpmt gpdf/Lin_Mar_05revised.pdf. Accessed 26 Apr 2020

84. Korst JJ, Johnston JD, Butler K, Bianco EJ, Conover LH, Woodward RB (1968) J Am Chem Soc 90:439-457

85. Gurevich AI, Karapetyan MG, Kolosov MN, Korobko VG, Onoprienko VV, Popravko SA, Shemyakin MM (1967) Tetrahedron Lett 8:131-134

86. Gáveby BMG, Huffman JC, Magnus P (1982) J Org Chem 47:3779-3780

87. Green A, Boothe JH (1960) J Am Chem Soc 82:3950-3953

88. Gurevich AI, Karapetyan MG, Kolosov MN (1966) Khim Prirodn Soedin Akad Nauk Uz SSSR 1966:141-142

89. von Wittenau MS (1964) J Org Chem 29:2746-2748

90. http://www.spiegel.de/spiegel/print/d-45954050.html. Accessed 26 Apr 2020

91. Muxfeldt H, Hardtmann G, Kathawala F, Vedejs E, Mooberry JB (1968) J Am Chem Soc 90:6534-6536

92. Muxfeldt H, Haas G, Hardtmann G, Kathawala F, Mooberry JB, Vedejs E (1979) J Am Chem Soc 101:689-701

93. http://www.kn-online.de/Lokales/Ploen/Neues-Verfahrenmachte-Hans-Muxfeldt-beruehmt. Accessed 26 Apr 2020

94. Tatsuta K, Yoshimoto T, Gunji H, Okado Y, Takahashi M (2000) Chem Lett 2000:646-647

95. Prein M, Adam W (1996) Angew Chem Int Ed 35:477-496

96. Stork G, La Clair JJ, Spargo P, Nargund RP, Totah N (1996) J Am Chem Soc 118:5304-5305

97. Stork G, Haggedorn AA III (1978) J Am Chem Soc 100:3609-3611

98. Charest MG, Lerner CD, Brubaker JD, Siegel DR, Myers AG (2005) Science 308:395-398

99. Sun C, Wang Q, Brubaker JD, Wright PM, Lerner CD, Noson K, Charest M, Siegel DR, Wang YM, Myers AG (2008) J Am Chem Soc 130:17913-17927
100. Wright PM, Seiple IB, Myers AG (2014) Angew Chem Int Ed 53:8840-8869

101. Charest MG, Siegel DR, Myers AG (2005) J Am Chem Soc 127:8292-8293

102. Vastrad BM, Neelagund SE (2011) Rec Res Sci Technol 3:1-8

103. Pereira JFB, Vicente F, Santos-Ebinuma VC, Araújo JM, Pessoa A, Freire MG, Coutinho JAP (2013) Proc Biochem 48:716-722

104. Zhang W, Watanabe K, Wang CCC, Tang Y (2007) J Biol Chem 282:25717-25725

105. Zhang W, Watanabe K, Cai X, Jung ME, Tang Y, Zhan J (2008) J Am Chem Soc 130:6068-6069

106. Pickens LB, Tang Y (2009) Metab Eng 11:69-75

107. http://www.genome.jp/kegg/pathway/map/map00253.html. Accessed 26 Apr 2020

108. Wang P, Bashiri G, Gao X, Sawaya MR, Tang Y (2013) J Am Chem Soc 135:7138-7141

109. Zhu T, Cheng X, Liu Y, Deng Z, You D (2013) Metab Eng 19:69-78

110. https://www.genome.jp/dbget-bin/www_bget?K14257+R05456. Accessed 31 Dec 2020

111. Leo Industrie Chimiche Farmaceitiche SpA (1963) BE 628142 (Clomocyclin)

112. Cheney LC, Risser WC, Gottstein WJ (1963) US 3104240 (Rolicyclin)

113. Gottstein WJ, Minor WF, Cheney LC (1959) J Am Chem Soc $81: 1198-1201$

114. Blackwood RK, Perry G, Brunings KJ (1962) US 3042716 (Lymecyclin)

115. Blackwood RK, Beereboom JJ, Rennhard HH, von Wittenau MS, Stephens CR (1963) J Am Chem Soc 85:3943-3953

116. Blackwood RK, Rennhard HH, Beereboom JJ, Stephens CR (1965) US 3200149

117. von Wittenau MS, Beereboom JJ, Blackwood RK, Stephens CR (1962) J Am Chem Soc 84:2645-2647

118. Blackwood RK, Rennhard HH, Beereboom JJ, Stephens CR (1965) US 3165531

119. McCormick JRD, Jensen ER (1962) US 3019260

120. Stephens CR, Murai K, Rennhard HH, Conover LH, Brunings KJ (1958) J Am Chem Soc 80:5324-5325

121. Stephens CR Jr, Beereboom JJ, Rennhard HH, Gordon PN, Murai K, Blackwood RK, von Wittenau MS (1963) J Am Chem Soc 85:2643-2652

122. Chen D, Da S, Li Y (2008) Chin J Pharmaceut 39:325-327

123. Church RFR, Schaub RE, Weiss MJ (1971) J Org Chem 36:723-725

124. Martell MJ Jr, Boothe JH (1967) J Med Chem 10:44-46

125. Petisi J, Boothe JH (1965) US 3226436

126. Winterbottom R, Kissman HM (1967) US 3345410

127. Boothe JH, Petisi J (1964) US 3148212

128. Sum PE, Lee VJ (1994) US 5284963

129. Zhou R (2012) CN 103044280

130. Li J, Pang Z (2013) CN 103044281

131. Nelson ML, Frechette R, Viski P, Ismail M, Bowser T, Dumornay J, Rennie G, Liu G, Koza D, Sheahan P, Stapleton K, Hawkins P, Bhatia B, Verma A, McIntyre L, Warchol T (2002) WO 2002004406 (Paratek Pharmaceuticals)

132. Nelson ML, Ohemeng K, Frechette R, Ismail MY, McIntyre L, Bowser T (2004) WO 2004091513 (Paratek Pharmaceuticals)

133. Ohemeng K, Amoo V, Kim O, Bowser T, Assefa H, Bhatia B, Berniac J, Chen J, Grier M, Honeyman L, Pan J, Mechiche R (2005) WO 2005009944 (Paratek Pharmaceuticals)

134. https://www.wired.com/2010/09/antibiotic-beer. Accessed 24 May 2020

135. Honeyman L, Ismail M, Nelson ML, Bhatia B, Bowser TE, Chen J, Mechiche R, Ohemeng K, Verma AK, Cannon EP, MacOne 
A, Tanaka S, Levy S (2015) Antimicrob Agents Chemother 59:7044-7053

136. https://www.pharmacytimes.com/resource-centers/pneumococc al-disease/fda-approves-omadacycline-for-pneumonia-and-skininfection-treatments. Accessed 24 May 2020

137. Steenbergen J, Tanaka SK, Miller LL, Halasohoris SA, Hershfield JR (2017) Antimicrob Agents Chemother 61:e02434-e2516. https://doi.org/10.1128/AAC.02434-16

138. S Johnson, T Warchol (2008) WO 2008134048 (Paratek Pharmaceuticals)

139. Chung JYL, Hartner FW, Cvetovich RJ (2008) Tetrahedron Lett 49:6095-6100

140. Einhorn A, Bischkopff E, Szelinski B, Schupp G, Spröngerts E, Ladisch C, Mauermayer T (1905) Justus Liebigs Ann Chem 343:207-305

141. P Abato, H Assefa, J Berniac, B Bhatia, T Browser, M Grier, L Honeyman, M Ismail, OK Kim, M Nelson, J Pan, A Verma (2008) WO 2008079339 (Paratek Pharmaceuticals)

142. Moore AY, Charles JEM, Moore S (2019) Future Microbiol 14:1235-1242

143. Kaul G, Saxena D, Dasgupta A, Chopra S (2019) Drugs Today (Barc) 55:615-625

144. Nelson ML, Honeyman L (2011) US 20110207951 (Paratek Pharmaceuticals)

145. Nelson ML, Honeyman L (2012) US 8288570 (Paratek Pharmaceuticals)

146. C Coulter, SM Johnston, F Seyedi (2016) US 20160200671 (Paratek Pharmaceuticals)

147. H Assefa, B Bhatia, M Draper, L Honeyman, DP Molnar (2008) WO 2008079363 (Paratek Pharmaceuticals)

148. Baillargeon P, Stille JK (1986) J Am Chem Soc 108:452-461

149. Allred TK, Manoni F, Harran PG (2017) Chem Rev 117:11994-12051

150. Brubaker JD, Myers A (2007) Org Lett 9:3523-3525
151. Hlavka JJ, Krazinski H, Boothe JH (1962) J Org Chem 27:3674-3675

152. Xiao XY, Hunt DK, Zhou J, Clark RB, Dunwoody N, Fyfe C, Grossman TH, O'Brien WJ, Plamondon L, Roenn M, Sun C, Zhang WY, Sutcliffe JA (2012) J Med Chem 55:597-605

153. Clark RB, Hunt DK, He M, Achorn C, Chen CL, Deng Y, Fyfe C, Grossman TH, Hogan PC, O'Brien WJ, Plamondon L, Roenn M, Sutcliffe JA, Zhu Z, Xiao XY (2012) J Med Chem 55:606-622

154. Zhou J, Xiao XY, Plamondon L, Hunt DK, Clark RB, Zahler RB (2010) WO 2010017470 (Tetraphase Pharmaceuticals)

155. Ronn M, Zhu Z, Hogan PC, Zhang WY, Niu J, Katz CE, Dunwoody N, Gilicky O, Deng Y, Hunt DK, He M, Chen CL, Sun C, Clark RB, Xiao XY (2013) Org Proc Res Dev 17:838-845

156. Zhang WY, Hogan PC, Chen CL, Niu J, Wang Z, Lafrance D, Gilicky O, Dunwoody N, Ronn M (2015) Org Process Res Dev 19:1784-1795

157. Zhang WY, Chen CL, He M, Zhu Z, Hogan P, Gilicky O, Dunwoody N, Ronn M (2017) Org Process Res Dev 21:377-386

158. Zhang WY, Che Q, Crawford S, Ronn M, Dunwoody N (2017) J Org Chem 82:936-943

159. Zincke T (1900) J Prakt Chem 61:561-567

160. Zincke T (1900) J Prakt Chem 63:183-187

161. WY Zhang, D LaFrance, M P Ronn (2016) WO 2016065290 (Tetraphase Pharmaceuticals)

162. Balz G, Schiemann G (1927) Chem Ber 1927:51186-51190

Publisher's Note Springer Nature remains neutral with regard to jurisdictional claims in published maps and institutional affiliations. 